\title{
Actividad biológica e inmunológica de las isoformas de carga de la hormona luteinizante bovina
}

\author{
Biological and immunological activity in bovine \\ luteinizing hormone charge isoforms
}

\author{
Álvaro Ortegaa, Aleida Olivaresb, Clara Murciaa, Daniel Díazc, Everardo González-Padillaa, \\ Arnulfo Monteroa, Gabriel Gutiérrez Ospinac, Gerardo Perera-Marína
}

\begin{abstract}
RESUMEN
La hormona luteinizante (LH) sufre modificaciones postraduccionales que dan origen a isoformas de carga. El estudio determinó la actividad biológica (B) e inmunológica (I) de distintas isoformas de LH bovina. Las isoformas se aislaron mediante el cromatoenfoque a partir del extracto glicoprotéico obtenido de lóbulos anteriores de hipófisis de bovino. La actividad biológica se evaluó en un bioensayo in vitro midiendo la producción de AMPc. La actividad inmunológica se midió con un radioinmunoensayo (RIA) específico para LH. EI USDA-bLH-B5 se utilizó como referencia. Las isoformas se agruparon tomando como referencia el rango de $\mathrm{pH}$ de elución, en básicas $(\mathrm{A}, \mathrm{pH}, 10.75-9.75 ; \mathrm{B}, \mathrm{pH}, 9.58-8.41)$, neutras ( $\mathrm{C}, \mathrm{pH}, 7.98-6.89)$ y ácidas ( $\mathrm{D}, \mathrm{pH}, 6.88-5.41 ; \mathrm{E}, \mathrm{pH}, 5.36-3.46)$. El peso molecular del heterodímero de cada isoforma y del estándar fue similar, estimado en $36.5 \mathrm{kDa}$. La actividad inmunológica y biológica se comportó de forma dosis-dependiente. Con respecto al estándar, se requirió una mayor concentración de proteína de cada isoforma para obtener el IC50 en la curva de inhibición. En el bioensayo, el valor EC50 para la producción de AMPc fue significativamente diferente entre isoformas; la isoforma neutra mostró un EC50 inferior lo que se interpretó como la proteína más bioactiva, en contraste, la isoforma ácida, mostró un valor de EC50 superior y resultó ser la menos bioactiva; la básica tuvo un comportamiento intermedio $(P<0.05)$. En conclusión, los resultados sugieren un efecto diferenciado de las isoformas de carga, sobre la producción cuantitativa de AMPc por unidad de LH inmunoreactiva.
\end{abstract}

PALABRAS CLAVE: Hormona luteinizante, Actividad biológica, Actividad inmunológica.

\begin{abstract}
Luteinizing hormone (LH) undergoes posttranslational modifications that originate different charge isoforms. The study evaluated the differences in biological (B) and immunological (I) activity between isoforms of bovine LH. Isoforms were isolated by chromatofocusing from anterior pituitary glycoprotein extract. The biological activity was evaluated in an in vitro bioassay. Immunological activity was measured with a radioimmunoassay (RIA) specific for LH. The USDA-bLH-B5 standard was utilized as the reference. LH isoforms were grouped by their pH range of elution, in basic ( $\mathrm{A}, \mathrm{pH}, 10.75-9.75 ; \mathrm{B}, \mathrm{pH} 9.58-8.41)$, neutral $(\mathrm{C} \mathrm{pH}, 7.98-6.89)$ and acidic ( $\mathrm{D}, \mathrm{pH}, 6.88-5.41 ; \mathrm{E}, \mathrm{pH} 5.36-3.46)$. The molecular weight of the heterodimer of each isoform was similar to the LH standard, estimated to be $36.5 \mathrm{kDa}$. Immunological and biological activity behaved in a dose-dependent manner. With respect to the LH standard, all isoforms required higher protein concentration to reach the IC50 of the inhibition curve. In the bioassay EC50 value for CAMP production was significantly different among isoforms; the neutral isoform showed a lower EC50 which was interpreted as more bioactive, the acidic isoform E showed an EC50 being the least bioactive and the basic was intermediate $(P<0.05)$. In conclusion, the results suggest a quantitative effect of LH charge isoforms on the cAMP production, per unit of immunoreactive LH in the bioassay.
\end{abstract}

KEY WORDS: Luteinizing hormone, Biological activity, Immunological activity.

Recibido el 9 de julio de 2015. Aceptado el 27 de noviembre de 2015.

a Facultad de Medicina Veterinaria y Zootecnia, Universidad Nacional Autónoma de México. Circuito exterior de Ciudad Universitaria S/N, CP.04510. México. pererag@unam.mx. Correspondencia al último autor.

b Unidad de Investigación Médica en Medicina Reproductiva, UMAE Hospital de Gineco Obstetricia no. 4 Luis Castelazo Ayala, IMSS, México.

c Instituto de Investigaciones Biomédicas, Universidad Nacional Autónoma de México. México.

Esta investigación se realizó con el soporte económico del Consejo Nacional de Ciencia y Tecnología (CoNaCyT), México, Proyecto No 78811. Gracias al NIH y al Dr. Parlow A.F. por proveer la bLH con alta pureza. Álvaro Ortega, Estudiante del posgrado de Ciencias de Producción y Salud Animal, UNAM, México. 


\section{INTRODUCCIÓN}

La hormona luteinizante (LH) es una glicoproteína presente en el lóbulo anterior de la hipófisis. La LH participa en la maduración folicular(1), la ovulación(2) y la formación y mantenimiento del cuerpo lúteo(3).

Durante el proceso de síntesis, la LH sufre modificaciones post-traduccionales como la incorporación de residuos de oligosacáridos del tipo $\mathrm{N}$-unidos con diferente porcentaje de sulfato y ácido siálico(4). Esta variación específica se considera la principal base bioquímica de la diferenciación entre las isoformas de carga de la LH intrahipofisaria y circulante(5).

El polimorfismo de las gonadotropinas se ha documentado en rumiantes $(6,7,8)$ y mediante el cromatoenfoque se han identificado isoformas de la LH en el suero $(9,10)$ como en la hipófisis $(11,12)$ y cuya proporción relativa es diferente(6). Incluso se sabe que la proporción de estas isoformas en la circulación es distinta en diversas etapas del ciclo estrall $(9,10)$.

La actividad biológica in vivo de distintas isoformas de $\mathrm{LH}$ de rumiantes ha generado resultados inconsistentes, sin embargo se establece que la mayor bioactividad la presentan las isoformas ácidas $(13,14,15)$. Esta inconsistencia en la respuesta biológica se ha atribuido a la tasa de depuración de cada isoforma, a la baja sensibilidad del ensayo (se requieren cantidades de microgramos de proteína) y a la variabilidad biológica de los animales empleados. En contraste, con el empleo de bioensayos in vitro, la mayor actividad biológica se presenta en las isoformas básicas(16,17), cuyo resultado no siempre es consistente debido al origen de las células de Leydig (rata o ratón) y que cuestiona la especificidad de especie cuando se utilizan ligandos de otras especies. Una alternativa relativamente reciente ha sido el desarrollo de bioensayos basados en la clonación de receptores para gonadotropinas $(18,19)$. Con la línea celular estable derivada de células embrionarias de riñón humano (HEK-293) y

\section{INTRODUCTION}

Luteinizing hormone (LH) is a glycoprotein present in the anterior lobe of the hypophysis. It participates in follicular maturation(1), ovulation(2), and luteal body formation and maintenance(3). During LH synthesis, the hormone experiences post-translational modifications such as incorporation of $\mathrm{N}$-type oligosaccharide residues linked to different proportions of sulfate and sialic acid(4). This specific variation is considered the principal biochemical foundation for differentiation between hypophysis and circulating LH charge isoforms(5).

Polymorphism in gonadotropins occurs in ruminants $(6,7,8)$. Using the chromatofocusing protein separation technique, different proportions of $\mathrm{LH}$ isoforms have been identified in the serum $(9,10)$ and hypophysis $(11,12)$. Indeed, the proportion of these isoforms in circulation differs in the different stages of the estrus cycle $(9,10)$.

Variability in the in vivo biological activity of $\mathrm{LH}$ isoforms in ruminants is the cause of inconsistent results, although acidic isoforms are regularly reported to have the highest bioactivity $(13,14,15)$. This variability in biological response has been attributed to each isoform's depuration rate, low assay sensitivity (micrograms of protein are required), and biological variability in experimental animals. In in vitro bioassays, the highest biological activity is present in the basic isoforms $(16,17)$. Results are not always consistent due to the origin (rat or mouse) of the Leydig cells, since the question remains of how species specific they can be when ligands from other species are used. A recently developed alternative is bioassays based on gonadotropin receptor cloning $(18,19)$. Using a stable cell line derived from HEK-293 cells transfected with rat LH receptor CDNA, evaluations have been done of CAMP production associated with distinct rat hypophysis extracts at a basic $\mathrm{pH}(20,21)$. This same biological model has been used to prove the constant affinity of bovine $\mathrm{LH}$ to the rat $\mathrm{LH}$ receptor(22). 
transfectada con el cDNA para el receptor de la LH de rata se ha logrado evaluar producción de AMPc asociada con distintos extractos hipofisarios de rata obtenidos a pH básico $(20,21)$; así mismo, con este modelo biológico se ha determinado la constante de afinidad de la $\mathrm{LH}$ bovina al receptor de la $\mathrm{LH}$ de rata(22).

Durante la última década, nuestro grupo de investigación se ha enfocado a aislar y caracterizar distintas isoformas de la $\mathrm{LH}$ de rumiantes para conocer la relación estructurafunción, su patrón de secreción en diferentes estadios fisiológicos y su actividad biológica. Sin embargo, debido al bajo rendimiento de las isoformas de tipo ácido y neutro, su caracterización biológica ha sido muy limitada. Es por esto que con la disposición del bioensayo basado en la clonación del receptor para $\mathrm{LH}$, se abre la posibilidad de cuantificar la bioactividad de este grupo de isoformas, que por su bajo rendimiento es difícil de monitorear.

Por lo tanto, el presente estudio se encaminó a evaluar el patrón de producción de AMPc por las células HEK-293 transfectadas con el cDNA para el receptor de LH de rata en respuesta a distintas isoformas de la LH bovina hipofisaria.

\section{MATERIAL Y MÉTODOS}

Para el desarrollo de este estudio fue necesario aislar y purificar las distintas isoformas de $\mathrm{LH}$ bovina en cantidades suficientes; determinar por medio del cromatoenfoque el punto isoeléctrico de cada isoforma, el peso molecular en SDS-PAGE y su caracterización inmunológica por medio de un radioinmunoensayo específico para LH y mediante el análisis por inmunotransferencia.

\section{Colección de hipófisis}

Se obtuvieron hipófisis de animales adultos sin considerar edad, sexo, ni condición fisiológica. Antes del sacrificio, cada animal se aturdió con una pistola de perno cautivo y después se separó la cabeza y se extrajo la hipófisis que
Over the last decade, our research group has focused on isolating and characterizing different ruminant $\mathrm{LH}$ isoforms to study their structurefunction relationship, their secretion patterns in various physiological conditions and their biological activity. Biological characterization has been especially challenging due to low yields of acidic and neutral isoforms. Advent of the $\mathrm{LH}$ receptor cloning bioassay has opened the possibility of quantifying bioactivity in these isoform groups, which is difficult to monitor due to their low yield.

The present study objective was to evaluate CAMP production by HEK-293 cells transfected with rat $\mathrm{LH}$ receptor $\mathrm{CDNA}$ in response to different bovine hypophysis LH isoforms.

\section{MATERIAL AND METHODS}

This study involved four main stages: 1) Isolation and purification of sufficient amounts of the different bovine LH isoforms; 2) Identification of each isoform's isoelectric point using chromatofocusing; 3) Quantification of each isoform's molecular weight by SDS-PAGE; and 4) Immunological characterization using a LH-specific immunoassay and immunotransference analysis.

\section{Hypophysis collection}

Hypophyses were extracted from adult bovines regardless of age, sex and physical condition. Prior to slaughter, each animal was stunned with a captive bolt gun. Once dead, the head was removed from each animal, the hypophysis extracted and deposited in phosphate buffer (0.05 M, pH 7.2). Excess tissue was removed from the gland, the posterior lobe discarded, and the anterior lobe lyophilized. All gland extraction and $\mathrm{LH}$ purification and isoform isolation steps were done at $4^{\circ} \mathrm{C}$.

Obtaining of glycoprotein extract from the hypophysis anterior lobe

An established protocol(13) was used to extract glycoprotein from 375 anterior lobes. Briefly, 
se colocó en amortiguador de fosfatos (0.05 M, $\mathrm{pH}$ 7.2). De cada glándula se retiró el exceso de tejido, se descartó el lóbulo posterior y el lóbulo anterior se liofilizó. Cada paso de extracción y purificación de la LH y sus isoformas se realizó a $4{ }^{\circ} \mathrm{C}$.

Obtención del extracto glicoprotéico (EGP) del lóbulo anterior de la hipófisis

El extracto glicoprotéico se obtuvo de 375 lóbulos anteriores de acuerdo al procedimiento descrito para rumiantes(13). En breve, los lóbulos anteriores liofilizados se hidrataron con acetato de amonio al $10 \%$, pH 7.0 que contenía 0.001 M de fenilsulfonilmetilfluoruro durante un período de $48 \mathrm{~h}$. Al término se licuaron y se homogeneizaron con la misma solución, y el extracto obtenido se conservó en agitación mecánica por 24 h; al término, el extracto se centrifugó a 10,000 xg por 45 min; el precipitado (R0) se almacenó y el sobrenadante se ajustó a $\mathrm{pH} 7.0$ y recibió gota a gota en agitación constante un volumen de etanol que correspondió al $40 \%$ del volumen total. Después de $16 \mathrm{~h}$ de agitación, la mezcla se centrifugó y la fracción de proteína presente en el precipitado (R1) se almacenó y el sobrenadante recibió un volumen de etanol de forma idéntica a lo previamente indicado, que correspondió al $85 \%$ del volumen total. Esta mezcla permaneció en reposo por $48 \mathrm{~h}$ y al término, las proteínas precipitadas se recuperaron por centrifugación. Este grupo de proteínas se identificó como el extracto glicoprotéico (EGP), que se resuspendió en agua desionizada, se dializó (Spectra/Por \# 4, cut off 12-14 kDa) durante $24 \mathrm{~h}$ con cambio de agua cada 8 h y después se liofilizó. Una segunda extracción se realizó a partir del R0 de la primera extracción repitiendo el proceso antes descrito. El segundo extracto glicoprotéico se mezcló con el primero para su purificación.

Purificación de EGP para la obtención de la LH

La LH se obtuvo por la purificación del extracto glicoprotéico en el intercambiador iónico, CM- lyophilized anterior lobes were hydrated for $48 \mathrm{~h}$ with $10 \%$ ammonium acetate ( $\mathrm{pH} 7.0)$ containing $0.001 \mathrm{M}$ phenylsulfonyl methyl fluoride. They were blended and homogenized with the same solution. The resulting extract was kept under constant agitation for $24 \mathrm{~h}$ and centrifuged at $10,000 \mathrm{xg}$ for $45 \mathrm{~min}$. The precipitate (R0) was stored. Supernatant was adjusted to $\mathrm{pH} 7.0$ and a volume of ethanol equivalent to $40 \%$ total volume added by drops under constant agitation. After $16 \mathrm{~h}$ agitation, the mixture was centrifuged, and the precipitate (protein fraction; R1) was discarded and stored. A volume of ethanol equal to that in the previous step was added to the supernatant, although in this case it was equal to $85 \%$ of total volume. This mixture remained undisturbed for $48 \mathrm{~h}$ and the precipitated proteins recovered by centrifugation. This group of proteins Identified was named glycoprotein extract (GPE), was re-suspended in deionized water, dialyzed (Spectra/Por \# 4, 12-14 kDa cut-off) for $24 \mathrm{~h}$ with the water changed every $8 \mathrm{~h}$, and lyophilized. A second extraction was done to the R0 precipitate from the first extraction step, following the above process. This second GPE was mixed with the first before purification.

\section{GPE purification for $\mathrm{LH}$ isolation}

The GPE was purified in an ionic exchanger (CM-Sepharose) to isolate $\mathrm{LH}^{(13)}$. One gram GPE containing $256 \mathrm{mg}$ protein was resuspended in $0.005 \mathrm{M}$ ammonium acetate $(\mathrm{pH} \mathrm{5.1}$; elution buffer), agitated for $24 \mathrm{~h}$, and centrifuged $(10,000 \mathrm{xg}$ for $30 \mathrm{~min})$. The protein solution was applied to a pre-packed column (27.0 x $1.5 \mathrm{~cm}$ i.d.) with the cation exchanger previously adjusted with elution buffer, and stored at $4{ }^{\circ} \mathrm{C}$. The protein fraction was eluted at a $23 \mathrm{ml} / \mathrm{h}$ flow through an ammonium acetate gradient (0.005 M, pH 5.1; $0.1 \mathrm{M}, \mathrm{pH} \mathrm{6.8;} \mathrm{and} 1.0$ $\mathrm{M}$-glycine $0.1 \mathrm{M}, \mathrm{pH}$ 9.5). Two-milliliter fractions were collected during the chromatography run, and the protein elution pattern monitored at $280 \mathrm{~nm}$. When effluent optical density was close to zero, the buffer was changed. After elution, a $1 \mathrm{M} \mathrm{NaCl}$ solution was run through the column. 
Sepharosa(13). Un gramo de extracto que contenía $256 \mathrm{mg}$ de proteína se resuspendió en acetato de amonio $0.005 \mathrm{M}, \mathrm{pH} 5.1$ (amortiguador de elución), se agitó durante 24 h y se centrifugó (10,000 xg por $30 \mathrm{~min}$ ). La proteína en solución se aplicó a una columna $(27.0 \mathrm{~cm} \mathrm{X} 1.5$ d.i.) pre-empacada con el intercambiador catiónico, equilibrada previamente con el amortiguador de elución y conservada a $4^{\circ} \mathrm{C}$. La fracción de proteína se eluyó con un flujo de $23 \mathrm{ml} / \mathrm{h}$ a través de un gradiente de acetato de amonio $(0.005 \mathrm{M}, \mathrm{pH} 5.1 ; 0.1 \mathrm{M}$, pH 6.8 y 1.0 M-glicina $0.1 \mathrm{M}, \mathrm{pH} 9.5$ ) y durante la corrida cromatográfica se colectaron fracciones de $2 \mathrm{ml}$. El patrón de elución de la proteína se monitoreó a $280 \mathrm{~nm}$. Cada cambio de amortiguador se realizó cuando la densidad óptica del efluente fue cercana a cero. Una vez concluida la elución, la columna recibió una solución $\mathrm{NaCl} 1 \mathrm{M}$.

Los distintos picos de proteína en que se distribuyó la elución del extracto glicoprotéico se identificaron de acuerdo a su amortiguador; las fracciones que eluyeron con acetato de amonio $0.005 \mathrm{M}, \mathrm{pH} 5.1$ se denominaron $\mathrm{CM}$ $1 \mathrm{ab}, \mathrm{CM}-1 \mathrm{~cd}$ y $\mathrm{CM}-1 \mathrm{ef}$, respectivamente; el pico de proteína que eluyó con 0.1 M, pH 6.8 se denominó CM-2ab y la proteína que eluyó con 1.0 M-glicina $0.1 \mathrm{M}, \mathrm{pH} 9.5$ se identificó como CM-3ab y correspondió a la LH cruda. La fracción de proteína recuperada después de $\mathrm{NaCl}$ se denominó pico de sal. Los distintos picos de proteína, se dializaron y liofilizaron para su análisis.

Purificación de la fracción $C M-3 a b$ para la obtención de las isoformas de la LH

Las isoformas de la LH se obtuvieron después de la purificación de la fracción CM-3ab; esta proteína recuperada durante la purificación del EGP en CM-Sepharosa se caracterizó por su alto contenido de LH y un patrón electroforético similar al estándar de LH bovina, USDA-bLHB5. La fracción se sometió a un proceso de separación de acuerdo a carga eléctrica $(8,11)$. En breve, la proteína $(56 \mathrm{mg})$ se resuspendió
Elution of the GPE produced protein peaks identified based on the buffer. Fractions eluted with $0.005 \mathrm{M}$ ammonium acetate ( $\mathrm{pH}$ 5.1) were called CM-1ab, CM-1cd and CM-1ef. The protein eluted with $0.1 \mathrm{M}$ ammonium acetate $(\mathrm{pH} 6.8)$ was called CM-2ab, and that eluted with $1.0 \mathrm{M}$ ammonium acetate and $0.1 \mathrm{M}$ glycine ( $\mathrm{pH} 9.5)$, corresponding to raw $\mathrm{LH}$, was called $\mathrm{CM}-3 \mathrm{ab}$. The protein peak recovered after the $\mathrm{NaCl}$ run was called the salt peak (S). All the protein peaks were dialyzed and lyophilized until analysis.

CM-3ab purification for $\mathrm{LH}$ isoform isolation Isolation of $\mathrm{LH}$ isoforms was done by purifying the CM-3ab fraction. During GPE purification in CM-Sepharose, CM-3ab stood out for its high LH content and for having an electrophoretic pattern similar to that of the bovine LH standard (USDA-bLH-B5). For this reason, it was processed for separation by electrical charge $(8,11)$. Briefly, $56 \mathrm{mg}$ protein were resuspended in Pharmalyte $(\mathrm{pH} 8.0-10.5$, Pharmalyte $0.36 \mathrm{meq} / \mathrm{ml} \mathrm{pH}$, Pharmacia Biotech Piscataway, NY, USA), diluted to 1:45 with deionized water and $\mathrm{HCl}$ added to adjust suspension $\mathrm{pH}$ to 7.0 . This was then added to a column $(27 \times 0.7 \mathrm{~cm}$ i.d. $)$ prepacked with PBE-118 ionic exchanger (Polybuffer exchanger for chromatofocusing, capacity: $50.4 \mu \mathrm{mol}, \mathrm{pH}$ unit-1 ml-1, Pharmacia, Biotech, Piscataway, NY, USA), balanced with $0.025 \mathrm{M}$ triethylamine- $\mathrm{HCl}$ $(\mathrm{pH} 11.0)$ and stored at $4{ }^{\circ} \mathrm{C}$. Three milliliters Pharmalyte buffer $(\mathrm{pH}$ 7.0) were added to the column before protein elution to prevent exposure of the sample to an extreme $\mathrm{pH}$.

Protein fraction elution was done at a $7 \mathrm{ml} / \mathrm{h}$ flow rate, and $2 \mathrm{ml}$ fractions collected. Each fraction's $\mathrm{pH}$ was measured, and when a $\mathrm{pH}$ above 7.0 was detected in more than ten consecutive samples the elution buffer was changed to polybuffer 74 (Pharmacia, Biotech). This was diluted to 1:8 with deionized water, and adjusted to $\mathrm{pH} 3.5$ to elute proteins between $\mathrm{pH} 7.0$ and 3.5. Any protein clinging to the column after elution at pH 3.5 was 
en Pharmalyte ( $\mathrm{pH}$ 8.0-10.5, Pharmalyte 0.36 $\mathrm{meq} / \mathrm{ml} \mathrm{pH}$, Pharmacia Biotech Piscataway, NY), diluido 1:45 con agua desionizada, el que se ajustó con $\mathrm{HCl}$ a pH 7.0 y a la suspensión se aplicó a una columna $(27 \mathrm{~cm} \times 0.7 \mathrm{~cm}$ d.i.) pre-empacada con el intercambiador iónico PBE118 (Polybuffer exchanger for chromatofocusing, capacity: $50.4 \mu \mathrm{mol}$. pH unit ${ }^{-1} \mathrm{ml}^{-1}$, Pharmacia, Biotech, Piscataway, NY), equilibrada con 0.025 M trietilamina- $\mathrm{HCl}, \mathrm{pH} 11.0$ y conservada a 4 ${ }^{\circ} \mathrm{C}$. Previo a la elución de la proteína, la columna recibió $3 \mathrm{ml}$ de amortiguador Pharmalyte, $\mathrm{pH}$ 7.0 para evitar la exposición de la muestra a un $\mathrm{pH}$ extremo.

La fracción de proteína se eluyó con un flujo de $7 \mathrm{ml} / \mathrm{h}$ y se colectaron fracciones de $2 \mathrm{ml}$. El pH de cada fracción se midió, y cuando se detectó el $\mathrm{pH}$ de 7.0 en más de 10 fracciones consecutivas, el amortiguador de elución se cambió por el polybuffer 74 (Pharmacia, Biotech), diluido 1:8 con agua desionizada y ajustado a pH 3.5 para obtener proteínas eluídas entre un $\mathrm{pH} 7.0$ a 3.5. La proteína unida a la columna después de la elución a pH 3.5 se recuperó por la adición de $1.0 \mathrm{M} \mathrm{NaCl}$. Con el registro de $\mathrm{pH}$ y conocido el patrón de elución de la proteína a $280 \mathrm{~nm}$, se procedió a neutralizar cada fracción; las fracciones colectadas entre $\mathrm{pH} 11.0$ y 7.0 recibieron Tris$\mathrm{HCl}, 1.1 \mathrm{M}, \mathrm{pH} 7.4$ y las fracciones eluídas entre pH 6.99 y pH 3.5 así como las proteínas colectadas con $\mathrm{NaCl} 1 \mathrm{M}$ se neutralizaron con Imidazol $1.1 \mathrm{M}$. Una vez neutralizadas el total de las fracciones de proteína, las fracciones se agruparon en el rango de $\mathrm{pH}$ de elución del pico de proteína: básicas $(A, p H, 10.75-9.75$; $\mathrm{B}, \mathrm{pH}, 9.58-8.41)$, neutra $(\mathrm{C}, \mathrm{pH}, 7.98-6.89)$ y ácidas $(\mathrm{D}, \mathrm{pH}, 6.88-5.41 ; \mathrm{E}, \mathrm{pH}, 5.36-3.46)$. Los distintos picos de proteínas se dializaron de forma independiente y se liofilizaron hasta su análisis.

\section{Análisis electroforético (SDS-PAGE)}

El patrón electroforético y el peso molecular se determinaron mediante una electroforesis en placa con geles de poliacrilamida al $12.5 \%$ a recovered by adding $1.0 \mathrm{M} \mathrm{NaCl}$. Each fraction was then neutralized based on the $\mathrm{pH}$ record and the known protein elution pattern at 280 $\mathrm{nm}$. Fractions collected between $\mathrm{pH} 11.0$ and 7.0 were neutralized with $1.1 \mathrm{M}$ Tris $-\mathrm{HCl}$, and those eluded between $\mathrm{pH} 6.99$ and 3.5, as well as those collected with $1 \mathrm{M} \mathrm{NaCl}$, were neutralized with $1.1 \mathrm{M}$ imidazole. After all fractions were neutralized, they were grouped according to the $\mathrm{pH}$ range of the elution protein peak: basic (A, pH 10.75-9.75; $B$, pH 9.588.41); neutral ( $C, \mathrm{pH}$ 7.98-6.89); and acidic ( $D$, pH 6.88-5.41; $\mathrm{E}, \mathrm{pH}$ 5.36-3.46). The different protein peaks were dialyzed separately and then lyophilized.

\section{Electrophoretic (SDS-PAGE) analysis}

The protein fractions isolated during $\mathrm{LH}$ purification and their isoforms were analyzed with SDS-PAGE(23), and their electrophoretic patterns compared to the LH reference (USDAbLH-B5). The resulting gels were stained following manufacturer instructions (Silver Stain Kit, Bio-Rad Laboratories, Inc.). Prestained, low molecular-weight markers were used as references (Bio-Rad Laboratories, Inc.).

\section{Total protein quantification}

Protein content was quantified in each fraction isolated during the $\mathrm{LH}$ purification and their isoforms, according to Bradford method(24). Bovine serum albumin (BSA) was used as a reference standard.

\section{Immunological analysis of LH and its isoforms}

Identification of LH-immunoreactive proteins

The molecular weight of proteins immunoreactive to the LH was determined through immunoblotting(25) The reference standard (USDA-bLH-B5), a protein fraction, or an isoform were analyzed by SDS-PAGE at a concentration of $100 \mathrm{ng}$ of protein. At the end of electrophoresis, the proteins present in the gel were transferred (200 mA/75 min: Trans-Blot Semi-Dry, Bio- 
pH 8.6 en presencia de dodecil sulfato de sodio(23) en aquellas fracciones de proteína obtenidas durante la purificación de la LH y sus isoformas. El patrón electroforético se comparó con la LH de referencia (USDA-bLH-B5). Una vez concluida la electroforesis, el gel se tiñó con plata siguiendo las especificaciones del estuche comercial (Silver Stain Kit, Bio-Rad, Laboratories, Inc). Como referencia se utilizaron marcadores preteñidos de bajo peso molecular (Bio-Rad Laboratories, Inc).

\section{Cuantificación de proteínas totales}

La concentración de proteína se determinó en cada fracción obtenida durante la purificación de la LH y sus isoformas por el método de Bradford(24). Se utilizó como estándar a la albúmina sérica bovina (BSA).

\section{Análisis inmunológico de la LH y sus isoformas}

Identificación de proteínas inmunoreactivas a $L H$

El peso molecular de las proteínas inmunoreactivas a LH se determinó por medio de la inmunotransferencia(25). El análisis se inició después de concluida la electroforesis en placa con geles de poliacrilamida al $12.5 \%$ a pH 8.6 en presencia de dodecil sulfato de sodio (SDSPAGE). En breve, $100 \mathrm{ng}$ de proteína del patrón de referencia USDA-bLH-B5 o de las distintas fracciones obtenidas durante la extracción y purificación de la LH y sus isoformas se transfirieron (Trans-Blot Semi-Dry (Bio-Rad, USA), $200 \mathrm{~mA} / 75 \mathrm{~min}$ ) a una membrana de nitrocelulosa (0.45 $\mu \mathrm{m}$ trans, blot, Bio-Rad). Transferidas las proteínas a la membrana de nitrocelulosa se incubó a $4{ }^{\circ} \mathrm{C}$ durante $16 \mathrm{~h}$ con el anticuerpo primario generado en conejo (antioLH-26) a una dilución 1:1000. Al término, la membrana se incubó durante $60 \mathrm{~min}$ a temperatura ambiente con el anticuerpo secundario (anti IgG de conejo generado en cabra y conjugado a peroxidasa, Jackson Immuno Research) diluido 1:20,000. El revelado se realizó por quimioluminiscencia (ImmobilonTM
Rad, USA) to a nitrocellulose membrane ( 0.45 $\mu \mathrm{m}$ Trans-Blot, Bio-Rad). The membranes were incubated at $4{ }^{\circ} \mathrm{C}$ for $16 \mathrm{~h}$ with a $1: 1000$ dilution of rabbit-generated primary antibody (anti-oLH26). They were then incubated for $60 \mathrm{~min}$ at room temperature with a 1:20,000 dilution of the secondary antibody (rabbit anti-IgG generated in goat and conjugated to peroxidase; Jackson Immuno Research). The membranes were viewed with chemiluminscence (ImmobilonTM Western Chemiluminescent HRP Substrate, Millipore Corporation, Billerica, MA, USA).

\section{Quantification of immunoreactive $L H$}

Immunoreactive LH was quantified with liquidphase radioimmunoassay (RIA) after validation with bovine $\mathrm{LH}(11)$. Each protein fraction from $\mathrm{LH}$ purification and their isoforms were analyzed at six doses $(0.2,0.4,0.8,1.6,3.2$ and $6.4 \mathrm{ng}$ protein/tube), with four replicates per dose. The LH reference (USDA-bLH-B5) was used as a standard at eight doses $(0.01,0.1,0.25,0.5$, $1.0,2.5,5.0$ and $10 \mathrm{ng} /$ tube). To create a tracer, NaI125 was incorporated into the USDAbLH-B5 following the IODO-GEN method(11). Primary antibody (anti-oLH-26) was used at a $1: 40,000$ dilution in the presence of normal rabbit serum (1:1600). Precipitation of the antigen-antibody complex occurred after $24 \mathrm{~h}$ at $4{ }^{\circ} \mathrm{C}$ with the secondary antibody (anti-IgG from rabbit generated in burro, $1: 80$ ). After addition of $1 \mathrm{ml} 0.05 \mathrm{M}$ PBS buffer ( $\mathrm{pH} 7.2)$ containing $0.1 \% \mathrm{BSA}$, the immunoprecipitated fraction was separated from the unbonded fraction by centrifuging at $1,500 \mathrm{xg}$ for $15 \mathrm{~min}$ at $4{ }^{\circ} \mathrm{C}$. A gamma radiation counter was used to analyze the immunoprecipitated fraction. Assay sensitivity was $0.1 \mathrm{ng} /$ tube. Using the reference curve EC50 as the dose value parameter, intra-assay variation was $2 \%$ and interassay variation was $5 \%$.

Quantitative LH concentration was measured by calculating IC50, defined as the protein concentration ( $\mathrm{ng}$ protein or $\mathrm{LH} / \mathrm{tube}$ ) that caused $50 \%$ inhibition of the $\% \mathrm{~B} / \mathrm{Bo}$ response. 
Western Chemiluminescent HRP Sustrate, Millipore Corporation, Billerica, MA, USA).

Cuantificación de la LH inmunoreactiva (irLH)

La determinación cuantitativa de la $\mathrm{LH}$ inmunoreactiva se determinó con un radioinmunoensayo (RIA) en fase líquida, validado previamente para la LH bovina(11). Cada fracción obtenida durante la purificación de la LH y sus isoformas se analizó a las dosis de $0.2,0.4,0.8,1.6,3.2$ y 6.4 ng de proteína/ tubo en cuatro réplicas y como estándar se utilizó al USDA-bLH-B5 a las dosis de 0.01, 0.1, $0.25,0.5,1.0,2.5,5.0$ y $10 \mathrm{ng} /$ tubo. El trazador se formó con la incorporación del NaI125 al USDA-bLH-B5 mediante el método del IODOGEN(11). El anticuerpo primario (anti-oLH-26) generado en conejo se utilizó a una dilución de trabajo 1:40,000 en presencia de suero normal de conejo, 1:1600 y la precipitación del complejo antígeno-anticuerpo se obtuvo después de $24 \mathrm{~h}$ de incubación a $4^{\circ} \mathrm{C}$ con el anticuerpo secundario (anti-IgG de conejo generado en burro, 1:80). Finalmente, la fracción inmunoprecipitada se separó de la fracción no unida por centrifugación $\left(1,500 \mathrm{xg}\right.$ por $15 \mathrm{~min}$ a $\left.4^{\circ} \mathrm{C}\right)$ previa adición de $1 \mathrm{ml}$ de amortiguador PBS $0.05 \mathrm{M}, \mathrm{pH} 7.2$ que contenía BSA al $0.1 \%$. La fracción inmunoprecipitada se analizó en un contador de radiaciones gamma. La sensibilidad del ensayo fue de $0.1 \mathrm{ng} /$ tubo y el coeficiente de variación intra e interensayo tomando como parámetro el valor de la dosis al EC50 de la curva de referencia correspondió al 2 y $5 \%$, respectivamente.

La concentración cuantitativa de la LH se determinó a partir del cálculo del parámetro IC50, definido como la concentración de proteína (ng de proteína o LH/tubo) que causó el $50 \%$ de inhibición en la respuesta del \%B/Bo. Para lo anterior se utilizó el programa estadístico Prism 6.0 (GraphPad Software, Inc., USA) que incluyó la ecuación de Hill. Ambos parámetros, IC50 y la pendiente de Hill se compararon con la prueba $\mathrm{F}$ de la suma de cuadrados, probando como hipótesis nula que estos parámetros son
This calculation was done using the Prism 6.0 (Graph Pad Software, Inc., USA) program, which includes the Hill equation. The IC50 and Hill slope (h) values were compared with the sumsquared F-test using a null hypothesis of the parameters being identical between each evaluated hormone pair; if a $P>0.05$ value is generated the parameter is deemed the same for both fits(26). A one-way ANOVA and a Tukey multiple comparison test were applied to identify significant differences $(P<0.05)$ between the tested isoforms $(27,28)$.

\section{Measuring LH isoform biological activity}

Biological activity was quantified by measuring CAMP production in three replicates per dose in three independent assays. HEK-293 cells(20) transfected with rat LH recombinant receptor cDNA (provided by Dr. Mario Ascoli, Iowa University, Iowa City, IA,USA) were stimulated with the reference pattern (USDA-bLH-B5) or one of the isoforms. These were differentiated when their isoelectric points (IEP) were sufficiently separated between proteins, and each represented a LH polymorphism. Based on these criteria, three isoforms were analyzed: basic ( $\mathrm{B}, \mathrm{pH}$ 9.58-8.41); neutral ( $\mathrm{C}, \mathrm{pH}$ 7.986.89); and acidic ( $\mathrm{E}, \mathrm{pH}$ 5.36-3.46).

The HEK-293 cells were cultured in a $162 \mathrm{~cm}^{2}$ culture box (Costar, Cambridge, MA, USA) containing high glucose Dulbecco's Modified Eagle Medium (DMEM) supplemented with $5 \%$ lamb fetal serum, $0.002 \mathrm{M} \mathrm{L-glutamine,}$ $100 \mu \mathrm{g} / \mathrm{ml}$ geneticine, $50 \mathrm{UI} / \mathrm{ml}$ penicillin and $100 \mu \mathrm{g} / \mathrm{ml}$ streptomycin. Cells with $90 \%$ confluence were reseeded in 24-well boxes (Gibco, BRL) at a $5 \times 104$ concentration per well and incubated in a $5 \% \mathrm{CO}_{2}$ atmosphere for $24 \mathrm{~h}$ at $37^{\circ} \mathrm{C}$. The medium was then removed and the cells exposed for $24 \mathrm{~h}$ to increasing doses $(6.25,12.5$ 25.0, 50.0, 100.0 and $200.0 \mathrm{ng} / \mathrm{ml}$ ) of immunoreactive $\mathrm{LH}$ from USDA-bLH-B5 or an isoform. Each hormone was diluted in culture medium containing $0.0125 \mathrm{M}$ 3-isobutyl-1-methylxantine (phosphodiesterase inhibitor). 
idénticos entre cada par de hormonas evaluadas; si se obtiene un valor de $P>0.05$, se concluye que el parámetro es el mismo para los dos ajustes(26). Adicionalmente, se utilizó ANOVA de una vía seguida de la prueba de comparación múltiple de Tukey para determinar diferencias significativas $(P<0.05)$ entre las isoformas ensayadas $(27,28)$.

Determinación de la actividad biológica de las isoformas de la $\mathrm{LH}$

La actividad biológica se determinó midiendo la producción de AMPc en tres réplicas por dosis en tres ensayos independientes. En breve, las células HEK-293(20) transfectadas con el cDNA del receptor recombinante de $\mathrm{LH}$ de rata (proporcionadas por el Dr. Mario Ascoli, Iowa University, Iowa City, IA), se estimularon con el patrón de referencia (USDA-bLH-B5) o con cada isoforma, que por su punto isoeléctrico (pI) representó el polimorfismo de la LH y cuyo pI se encontró lo suficientemente alejado entre proteínas; con base en estos criterios se analizaron las isoformas, básica $(B, \mathrm{pH}$; 9.588.41), neutra $(\mathrm{C}, \mathrm{pH}$; 7.98-6.89) y ácida $(\mathrm{E}$, $\mathrm{pH} ; 5.36-3.46)$.

Para ello, las células HEK-293 transfectadas se cultivaron en caja de cultivo de $162 \mathrm{~cm}^{2}$ (Costar, Cambridge, MA, EUA) que contenía el medio DMEM (Dulbecco's Modified Eagle Medium) alto en glucosa, suplementado con $5 \%$ de suero fetal de ternera, $0.002 \mathrm{M}$ de L-glutamina, 100 $\mu \mathrm{g} / \mathrm{ml}$ de geneticina $50 \mathrm{UI} / \mathrm{ml}$ de penicilina y $100 \mu \mathrm{g} / \mathrm{ml}$ de estreptomicina. Las células confluentes en un $90 \%$ se resembraron en cajas de 24 pozos (Gibco, BRL) con una densidad de $5 \times 10^{4}$ células por pozo y se incubaron en una atmósfera de $5 \%$ de $\mathrm{CO}_{2}$ por $24 \mathrm{~h}$ a $37^{\circ} \mathrm{C}$. Al término, se retiró el medio y las células se expusieron durante $24 \mathrm{~h}$ a dosis crecientes de LH inmunoreactiva del USDAbLH-B5 o de cada isoforma (6.25, 12.5 25.0, $50.0,100.0$ y $200.0 \mathrm{ng} / \mathrm{ml})$. Cada hormona se diluyó en medio de cultivo que contenía $0.0125 \mathrm{M}$ de 3-isobutil-1-metilxantina (inhibidor de la fosfodiesterasa).
Total cAMP content was measured in the culture medium with liquid phase RIA(21). The CAMP tracer 2-0-monosuccinyl tyrosyl-methyl ester (Sigma) was labelled with Nal125 (Amersham International Limited, UK) following the chloramine-T method(29). The primary antibody (anti-cAMP, CV-27, NIADDK, Bethesda, MD, USA) was used at a 1:70,000 dilution in the presence of $0.005 \mathrm{M}$ sodium and $0.1 \%$ BSA (pH 6.1). Each reaction tube was incubated for $24 \mathrm{~h}$ at $4{ }^{\circ} \mathrm{C}$, and then the bonded antibody separated from the free CAMP by adding cold ethanol, and then centrifuging at $1,500 \mathrm{xg}$ for $30 \mathrm{~min}$ at $4{ }^{\circ} \mathrm{C}$. The immunoprecipitated fraction was analyzed in a gamma radiation counter. Assay sensitivity was $2.0 \mathrm{pmol} / \mathrm{ml}$ with a $2 \%$ intraassay variation coefficient, and a $5 \%$ interassay variation coefficient. Production of CAMP was calculated by interpolating from the CAMP 2-0monosuccinyl tyrosyl-methyl ester reference curve.

Each isoform's biological activity was measured by calculating the EC50 parameter, defined as the amount of $\mathrm{LH}(\mathrm{ng} / \mathrm{ml})$ required to generate a response equal to $50 \%$ of the maximum response under assay conditions $(26,27)$. For this purpose, the experimental data were fitted in four-parameter dose-stimulation response curves in the tested $\mathrm{LH}$ immunoreactive dose range for the standard and for each isoform. These calculations were done with the Prism 6.0 program (GraphPad Software, Inc., USA).

Using the fit curves, statistical comparisons were made of the EC50 parameters and Hill slope (h). These comparisons were done with the sum-of-squares F-test, testing the null hypothesis of the parameters being identical between each pair of evaluated hormones; a value of $P>0.05$ indicated the parameter was the same in both fits(27). A one-way ANOVA and the Tukey multiple comparison test were applied to identify significant differences $(P<0.05)$ between the relative bioactivity strength of each assayed isoform. 
El contenido de AMPc total se midió en el medio de cultivo a través de radioinmunoensayo en fase líquida(21). Para ello el trazador 2-0monosuccinil tirosil-metil éster de AMPc (Sigma) se radiomarcó con Na125I (Amersham International Limite, Reino Unido) mediante el método de la Cloramina-T(29). El anticuerpo primario (anti-AMPc, CV-27, NIADDK, Bethesda, MD, USA) se utilizó a una dilución de 1:70,000 en presencia de acetato de sodio $0.005 \mathrm{M}$ y albúmina sérica bovina al $0.1 \%, \mathrm{pH}$ 6.1. Cada tubo de reacción se incubó por $24 \mathrm{~h}$ a $4{ }^{\circ} \mathrm{C}$ y al término el anticuerpo unido se separó del AMPc libre después de agregar etanol frío y seguido de una centrifugación a 1,500 xg durante 30 min a $4^{\circ} \mathrm{C}$. La fracción inmunoprecipitada se analizó en un contador de radiaciones gamma. La sensibilidad del ensayo fue de $2.0 \mathrm{pmol} / \mathrm{ml}$ y el coeficiente de variación intra e interensayo fue de 2 y $5 \%$, respectivamente. La producción de AMPc se calculó por interpolación de los resultados en la curva de referencia de 2-0monosuccinil tirosil-metil éster de AMPc.

La actividad biológica para cada isoforma se determinó a través del cálculo del parámetro EC50, definido como la cantidad requerida de LH (ng/ml) que generó una respuesta al $50 \%$ de la respuesta máxima, bajo las condiciones establecidas en el ensayo $(26,27)$. Para ello, los datos experimentales se ajustaron en curvas dosis-respuesta de estimulación de cuatro parámetros, en el rango de la dosis de $\mathrm{LH}$ inmunoreactiva probada del estándar y de cada isoforma, utilizando el programa estadístico Prism 6.0 (GraphPad Software, Inc., USA).

A partir de las curvas de ajuste se realizaron comparaciones estadísticas de los parámetros EC50 y la pendiente de Hill (h). Para lo anterior se utilizó la prueba $\mathrm{F}$ de la suma de cuadrados, probando como hipótesis nula que los parámetros son idénticos entre cada par de hormonas evaluadas; si se obtiene un valor de $P>0.05$, se concluye que el parámetro es el mismo para los dos ajustes(27). Además, se utilizó ANOVA de una vía seguida de la prueba de comparación múltiple de Tukey para

\section{RESULTS}

Three fractions were generated during the anterior lobe extraction process. The first fraction, R0, corresponded to $63.2 \%$ (77.16 g) of the original weight. The second, R1, was obtained with $40 \%$ ethanol with a $9.03 \%$ $(11.02 \mathrm{~g})$ yield. The third was the GPE, recovered using $85 \%$ ethanol with a $8.24 \%$ (10.06 g) yield and a $226 \mu \mathrm{LH} / \mathrm{mg}$ protein concentration.

Five protein fractions resulted from GPE purification in the ionic exchanger (Figure 1(I)). Fraction $\mathrm{CM}-3 \mathrm{ab}$ exhibited the highest protein content and high immunoreactive $\mathrm{LH}$ content (Figure 1 (II)). In contrast, fractions $\mathrm{CM}-1 \mathrm{~cd}$ and $\mathrm{CM}-1$ ef had low LH and protein contents, and were excluded from the analysis.

In the electrophoresis patterns generated under non-reducing (NR) conditions (i.e. absence of $\beta$-mercaptoethanol) (Figure 1(II)), CM-3ab exhibited a pattern similar to that of the reference, consisting of two proteins with molecular weights of 36.5 and $23.4 \mathrm{kDa}$, respectively (Figure 1 (III)). Although both these proteins were present in the GPE, as well as $\mathrm{CM}-1 \mathrm{ab}$ and $\mathrm{CM}-2 \mathrm{ab}$, the pattern in the latter two fractions was more heterogeneous with an additional predominant, higher weight (56.0 $\mathrm{kDa}$ ) protein. Under reducing (R) conditions (i.e. presence of $\beta$-mercaptoethanol), CM-3ab exhibited three proteins with weights of 23.4, 20.8 and $17.0 \mathrm{kDa}$, respectively. Fractions CM$1 \mathrm{ab}$ and CM-2ab had a similar pattern, with addition of an even more dominant protein at $72.0 \mathrm{kDa}$. Based on their patterns, the latter two fractions were excluded, and $\mathrm{LH}$ charge isoforms were isolated only from fraction CM$3 a b(\mathrm{pH}$ 9.5).

In the PBE-118 ionic exchanger, the CM-3ab elution pattern exhibited five protein peaks along the $\mathrm{pH}$ gradient, each peak corresponding to an isoform (Figure 2(I)). Of the total recovered immunoreactive $\mathrm{LH}, 72.8 \%$ was obtained at a basic $\mathrm{pH}(\geq 7.5$, fractions $\mathrm{A}$ and $\mathrm{B}), 6.3 \%$ at a 
Figura 1. I) Patrón de elución del extracto glicoprotéico (GPE) en CM-Sepharosa. II) Concentración de proteína (mg) y LH inmunoreactiva para cada fracción. III) Patrón electroforético del USDA-bLH-B5, el (CPE) y de las fracciones con actividad inmunológica de LH. NR, condiciones no reductoras; $R$, reductoras

Figure1. I) Elution pattern of the glycoproteic extract (GPE) during its cation-exchange chromatography with CMSepharose. II) Table summarizing the protein concentration $(\mathrm{mg})$ and concentration of $\mathrm{LH}(\mu \mathrm{g} \mathrm{LH} / \mathrm{mg}$ protein) of each fraction. III) Electrophoretic pattern of the reference LH (USDA-bLH-B5), the GPE and the fractions with $\mathrm{LH}$ immunological activity under non-reducing (NR) and reducing $(\mathrm{R})$ conditions. Arrows indicated at proteins with molecular weights of $72,60,36.5,23.4,20.8,17.0 \mathrm{kDa}$, respectively

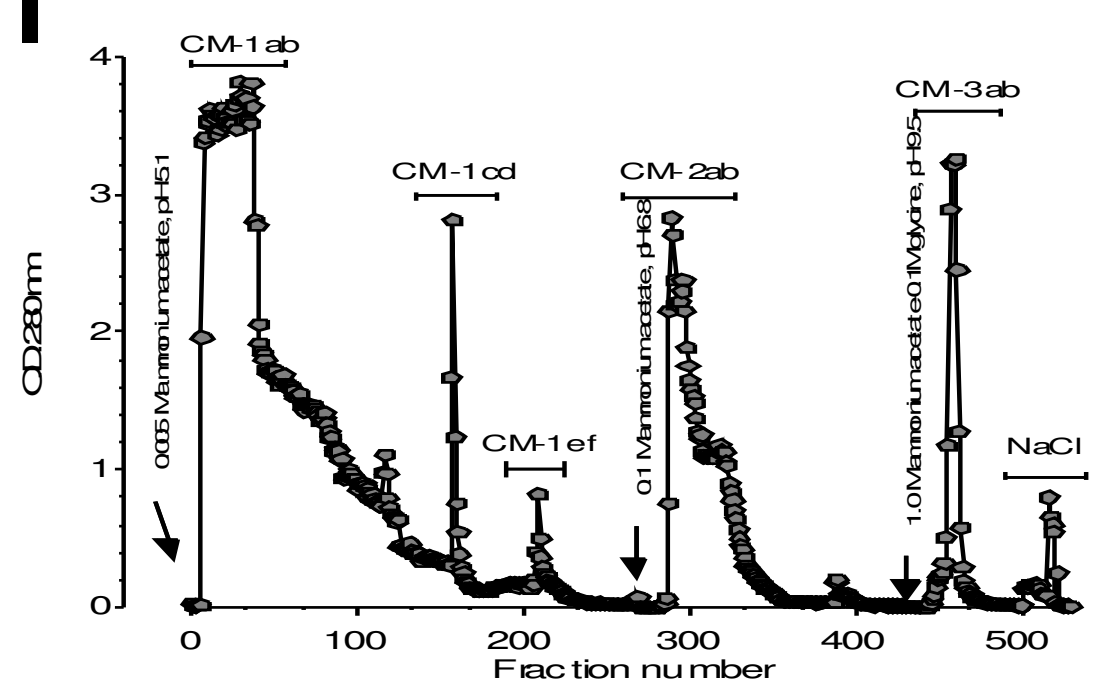

II

Fractions o btained during purification of glycopro tein extract (GPE)

\begin{tabular}{ccc}
\hline Fraction & Protein $(\mathrm{mg}) *$ & $\mathrm{tg}$ LH/mg protein ** \\
GPE & 256.0 & 226.0 \\
CM-1ab & 26.7 & 607.0 \\
CM-1cd & 6.6 & 20.0 \\
CM-1 ef & 0.8 & 11.4 \\
CM-2ab & 18.1 & 73.0 \\
CM-3ab & 55.8 & 727.5 \\
\hline EStimatedby Bradord
\end{tabular}

** Estimatedby RIA, equivalent to USDA-bLH-B5

III

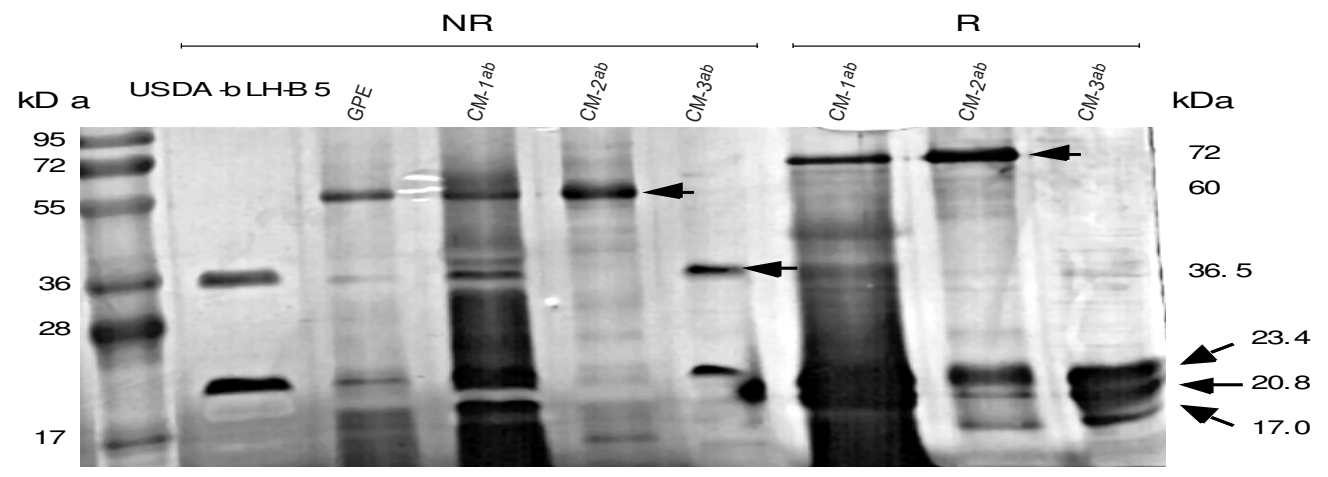


determinar diferencias significativas $(P<0.05)$ entre la biopotencia relativa de las isoformas ensayadas.

Figura 2. I) Patrón de elución de la fracción CM-3ab en el cromatoenfoque. Cada pico de proteína se identificó con una letra, comenzando con la proteína de elución a $\mathrm{pH}$ básico (A) y finalizando con la proteína que eluyó a $\mathrm{pH}$ ácido (E). La fracción $\mathrm{S}$ se obtuvo con 1.0M NaCl. II) Cuadro de rendimiento y concentración de $\mathrm{LH} / \mathrm{mg}$ de proteína para cada isoforma

Figure 2. I) Elution pattern of the CM-3ab fraction in chromatofocusing. Protein was monitored at $280 \mathrm{~nm}$ and each protein peak was identified with a letter, starting with the elution protein at basic $\mathrm{pH}(A)$ and ending with the eluted protein at acid $\mathrm{pH}(E)$. The protein that did not eluted with the gradient was obtained after, using $1.0 \mathrm{M}$ $\mathrm{NaCl}$ and was designated as $\mathrm{S}$. II) Table summarizing the protein concentration and LH-specific for each isoform

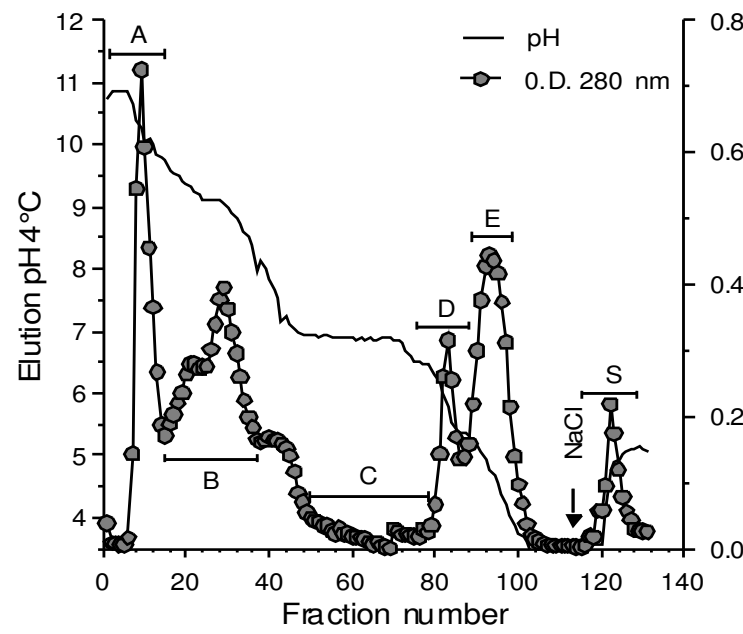

Purification of bovine $\mathrm{LH}$ is oforms from the CM-3ab fraction of GPE

\begin{tabular}{lcc}
\hline $\begin{array}{c}\text { Isofom } \\
\text { pH range })\end{array}$ & Protein $(\mathrm{mg}){ }^{*}$ & $\mathrm{tg}$ LH/mg protein ** \\
\hline $\mathrm{A}(10.75-9.75)$ & 1.0 & $112.5 \mathrm{t} 14.1$ \\
$\mathrm{~B}(9.58-8.41)$ & 17.9 & $673.1 \mathrm{t} 37.7$ \\
$\mathrm{C}(7.98-6.89)$ & 6.9 & $161.3 \mathrm{t} 12.9$ \\
$\mathrm{D}(6.88-5.41)$ & 7.9 & $232.9 \mathrm{t} 13.1$ \\
$\mathrm{E}(5.36-3.46)$ & 8.5 & $199.3 \mathrm{t} 5.3$ \\
$\mathrm{~S}$ & 0.4 & $16.0 \mathrm{t} 0.6$ \\
\hline * E stimated by Bradford & ${ }^{* *}$ E sti mate dby RIA
\end{tabular}

neutral pH (7.4 - 6.6, fraction $\mathrm{C})$, and $20.1 \%$ at an acidic $\mathrm{pH}(\leq 6.5$, fractions $\mathrm{D}$ and $\mathrm{E})$. Each isoform had different protein and immunoreactive LH contents (Figure 2(II)).

Under NR electrophoretic conditions (Figure 3(I), upper panel), each $\mathrm{LH}$ isoform exhibited a homogeneous pattern with two dominant protein bands ( 36.5 and $23.4 \mathrm{kDa}$ ) in a pattern similar to those of USDA-bLH-B5 and CM-3ab. Although the GPE and isoform $\mathrm{E}(\mathrm{pH} ; 5.36-3.46)$ had a pattern similar to those above, they also included

Figura 3. Patrón electroforético (I) y análisis por inmunotransferencia (II) de cada isoforma de LH bovina. USDA-bLH-B5, patrón de referencia; GPE, extracto glicoprotéico; fracción CM-3ab; isoformas, $\mathrm{A}(\mathrm{pH} 10.75$ 9.75); $\mathrm{B}$ (pH 9.58-8.41); C (pH 7.98-6.89); D (pH 6.885.41); $\mathrm{E}(\mathrm{pH}$ 5.36-3.46)

Figure 3. Electrophoretic pattern (I) and immunobloting electrophoretic pattern (II) for the standard bLH (USDAbLH-B5), glycoprotein extract (GPE), CM-3ab fraction, isoform A, pH 10.75-9.75; $\mathrm{B}, \mathrm{pH}$ 9.58-8.41; C, pH 7.986.89; $\mathrm{D}, \mathrm{pH}$ 6.88-5.41; $\mathrm{E}, \mathrm{pH}$ 5.36-3.46 in non-reducing and reducing conditions

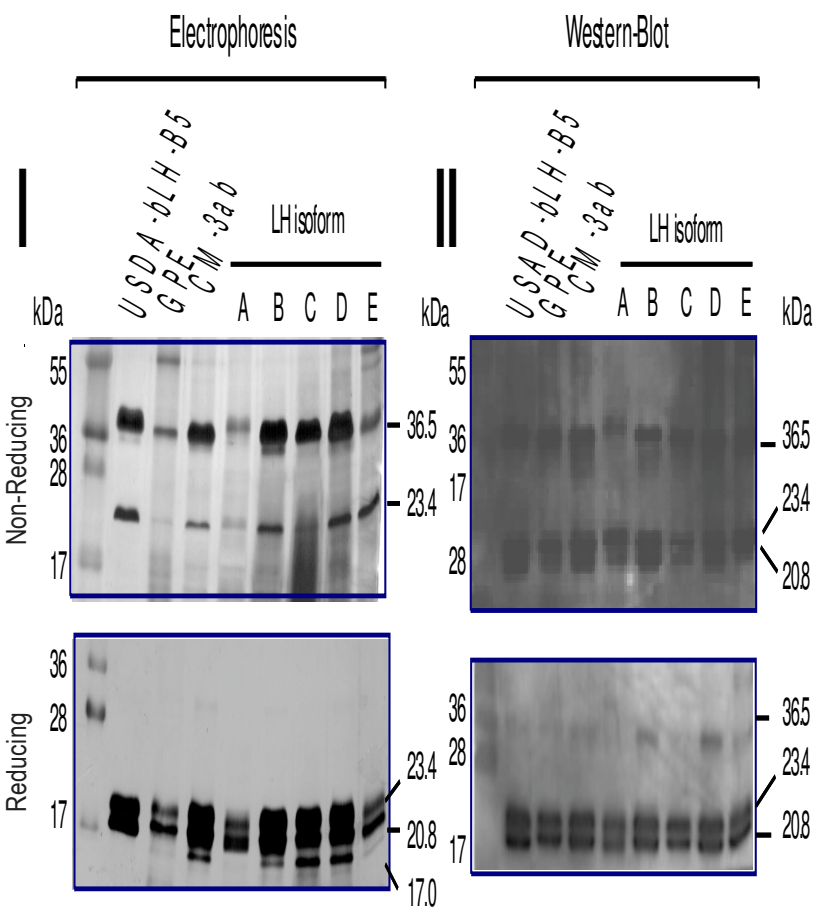




\section{RESULTADOS}

Durante el proceso de extracción de los lóbulos anteriores se generaron tres fracciones. El R0 que correspondió al $63.2 \%(77.16 \mathrm{~g})$ del peso original; el R1, que se obtuvo con el $40 \%$ de etanol, con un rendimiento del $9.03 \%(11.02 \mathrm{~g})$ y el extracto glicoprotéico (EGP) que se recuperó con el $85 \%$ de etanol, con un rendimiento del $8.24 \%(10.06 \mathrm{~g})$ y una concentración de 226 $\mu \mathrm{g}$ de $\mathrm{LH} / \mathrm{mg}$ de proteína.

Del EGP purificado en el intercambiador iónico se obtuvieron cinco fracciones de proteína (Figura 1(I)). La fracción CM-3ab mostró el mayor contenido de proteína y un alto contenido de LH inmunoreactiva (Figura 1(II)); en contraste, las fracciones $\mathrm{CM}-1 \mathrm{~cd}$ y $\mathrm{CM}-1$ ef mostraron un bajo contenido de LH y cantidad a $55.0 \mathrm{kDa}$ protein. Under R electrophoretic conditions (Figure 3(I), lower panel), all the isoforms exhibited the same pattern as the GPE, CM-3ab and USDA-bLH-B5. Of interest is the presence of a $17.0 \mathrm{kDa}$ protein in $\mathrm{CM}-3 \mathrm{ab}$ and the $B, C$ and $D$ isoforms.

Immunotransference analysis under NR conditions (Figure 3(II), upper panel) showed that the different isoforms maintained a $\mathrm{LH}$ immunoreactive protein pattern similar to that of USDA-bLH-B5 with the $36.5 \mathrm{kDa}$ protein most notable. Under $\mathrm{R}$ conditions, this protein almost disappears while lower weight proteins (23.4 and $20.8 \mathrm{kDa}$ ) increase in intensity.

When the LH isoform and CM-3ab fraction are compared to the reference standard in the RIA displacement curves (Figure 4), immunological

Figura 4. Curva dosis-respuesta en el sistema de RIA específico para LH. I) USDA-bLH-B5 y la fracción CM-3ab. II) USDA-bLH-B5 e isoformas básicas (A, pH, 10.75-9.75; $\mathrm{B}, \mathrm{pH}, 9.58-8.41$ ); USDA-bLH-B5 e isoforma neutra (C, pH, 7.98-6.89); USDA-bLH-B5 e isoformas ácidas (D, pH, 6.88-5.41 y E, pH 5.36-3.46). III) Parámetros de análisis de la relación B/Bo vs dosis

Figure 4. Inhibitory dose-response curves of a LH-specific RIA for the standard bLH (USDA-bLH-B5) and isoforms. I) The reference standard and CM-3ab fraction. II) Standard and basic isoforms (A, pH, 10.75-9.75, B, pH, 9.58-8.41); Standard and neutral isoform (C, pH 7.98-6.89); Standard and acidic isoforms (D, pH 6.88-5.41 and $\mathrm{E}, \mathrm{pH}$ 5.36-3.46). III) Table summarizing the analysis parameters of the $\mathrm{B} / \mathrm{Bo}$ vs dose

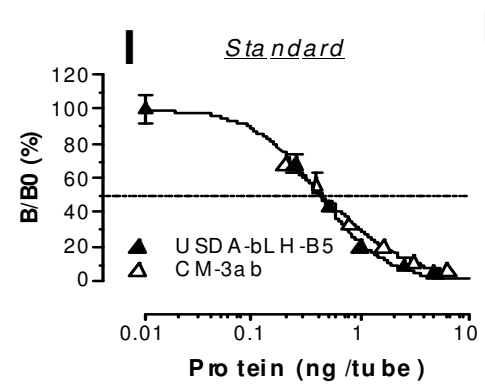

\begin{tabular}{|c|c|c|c|c|c|c|c|}
\hline & \multirow{2}{*}{$\begin{array}{l}\text { USD A- } \\
\text { bLH B } 5\end{array}$} & \multirow{2}{*}{$\sigma^{3^{2}}$} & \multicolumn{2}{|c|}{$B$ as ic } & \multirow{2}{*}{$\frac{\frac{\text { Isoform }}{\text { Neutral }}}{\text { C }}$} & \multicolumn{2}{|c|}{ A cid ic } \\
\hline & & & $\mathrm{A}$ & $B$ & & $\mathrm{D}$ & $E$ \\
\hline $\mathrm{IC}_{50}$ & 0.42 & 0.45 & $2.54^{*}, \mathrm{~b}$ & $0.63^{*}, \mathrm{a}$ & $1.95^{*}$ & $1.43^{*} \mathrm{a}^{\mathrm{a}}$ & $1.51^{*}$, \\
\hline$h$ & -1.4 & -1.0 & -1.6 & -1.3 & -1.5 & -1.2 & -1.0 \\
\hline $\mathrm{R}^{2}$ & 0.98 & 0.98 & 0.95 & 0.94 & 0.96 & 0.98 & 0.96 \\
\hline
\end{tabular}
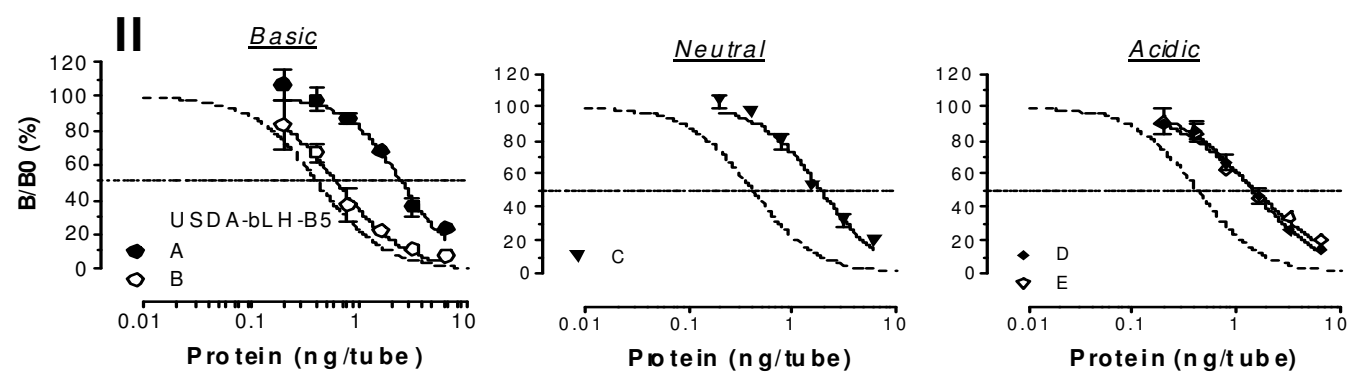
de proteína, por lo que se excluyeron del estudio y no se analizaron electroforéticamente. El patrón electroforético de aquellas fracciones con mayor contenido de proteína y LH se ejemplifica en la Figura 1(II).

De acuerdo al patrón electroforético, en ausencia de $\beta$-mercaptoetanol (condiciones no reductoras, $N R$ ), la fracción CM-3ab y el patrón de referencia presentaron un patrón similar que consistió de dos proteínas con un peso molecular de 36.5 y $23.4 \mathrm{kDa}$, respectivamente (Figura 1 (III)). A pesar de la presencia de estas dos proteínas en el extracto glicoprotéico y en las fracciones CM$1 \mathrm{ab}, \mathrm{CM}-2 \mathrm{ab}$, el patrón electroforético en estas últimas fracciones resultó más heterogéneo, y se observó una proteína predominante de mayor peso molecular $(56.0 \mathrm{kDa})$. En presencia de $\beta$-mercaptoetanol (condiciones reductoras, $\mathrm{R}$ ), el patrón electroforético de la fracción $\mathrm{CM}-3 \mathrm{ab}$ se caracterizó por la presencia de tres proteínas con un peso molecular de 23.4, 20.8 y 17.0 $\mathrm{kDa}$, respectivamente; las fracciones CM-1ab y CM-2ab presentaron un patrón similar, sin embargo en ellas se observó una proteína muy intensa de peso molecular de $72.0 \mathrm{kDa}$. Con base en este patrón electroforético se decidió que ambas fracciones de proteína se excluyeran del estudio, por lo tanto el grupo de isoformas de carga de $\mathrm{LH}$ se aislaron únicamente de la fracción CM-3ab ( $\mathrm{pH}$ 9.5).

El patrón de elución de la fracción $\mathrm{CM}$-3ab en el intercambiador iónico, PBE118, se distribuyó en cinco picos de proteína a través del gradiente de $\mathrm{pH}$; cada pico correspondió a una isoforma (Figura 2(I)). Del total de LH inmunoreactiva recuperada, el $72.8 \%$ se obtuvo a $\mathrm{pH}$ básico $(\geq 7.5$, fracciones $\mathrm{A}$ y $\mathrm{B})$, mientras que a $\mathrm{pH}$ neutro (7.4 a 6.6, fracción C) se recuperó el $6.3 \%$ y a $\mathrm{pH}$ ácido ( $\leq 6.5$, fracciones $\mathrm{D}$ y E) el $20.1 \%$. La cantidad de proteína y de LH inmunoreactiva para cada isoforma se resume en la Figura 2(II).

En el patrón electroforético en condiciones no reductoras (Figura 3(I), panel superior) cada isoforma de la LH mostró un patrón homogéneo con dos bandas de proteínas predominantes de activity (IC50) is similar between USDA-bLH-B5 and CM-3ab (Figure 4(II)). However, the IC50 for the reference was lower than those of the isoforms, indicating that the standard is immunologically more active versus the antibody used in the assay. The dose-response curve slopes of the standard and the isoforms did not differ, indicating the proteins' identity (Figure 4(III)).

Production of cAMP by HEK-239 cells in response to the immunoreactive $\mathrm{LH}$ standard and the $\mathrm{LH}$ isoforms was dose-dependent (Figure 5(I)). Calculation of EC50 as a proxy for biological activity on the normalized dose-response curve showed the standard and the isoforms to differ (Figure 5(II)). The neutral isoform had the lowest EC50 value, meaning it was the most biologically active, whereas the acidic isoform had the highest EC50 value and therefore the lowest bioactivity (Figure 5(III)). For the standard, the Hill slope (h) value differed from those of the basic and acidic isoforms, but not from that of the neutral isoform (Figure 5(III)).

\section{DISCUSSION}

Polymorphism in mammal LH is reflected in its physicochemical, immunological and biological properties. In vivo $(13,14,15)$ and in vitro $(16,17)$ bioassays have been done of biological activity in different LH isolates from ruminant hypophyses. The results indicate that basic isoforms are the most bioactive proteins in vitro, whereas acidic isoforms are more active in vivo. Recent developments include bioassays using cell lines that express gonadotropin receptors, which allow study of biologically functional proteins $(20,30)$.

The present study is the first time an in vitro bioassay using HEK-293 cells transfected with rat $\mathrm{LH}$ receptor cDNA has been applied to evaluate biological activity in different charge isoforms of bovine hypophysis(20). Quantitative CAMP production per immunoreactive $\mathrm{LH}$ unit differed between isoforms, with the neutral isoform having more activity than the basic and acidic isoforms. 
peso molecular de 36.5 y $23.4 \mathrm{kDa}$ respectivamente, patrón similar al USDA-bLH-B5 y a la fracción CM-3ab. A pesar que el extracto glicoprotéico (EGP) y la isoforma $\mathrm{E}(\mathrm{pH} ; 5.36-3.46)$ mostraron un patrón similar en ellos, se observó una proteína de $55.0 \mathrm{kDa}$. Asimismo, en condiciones reductoras, cada isoforma mostró el mismo patrón electroforético que el extracto glicoprotéico, la fracción CM-3ab y el USDAbLH-B5. Interesantemente, se presentó una banda de proteína de $17 \mathrm{kDa}$ particularmente en la fracción CM-3ab y en las isoformas B, C y D (Figura 3(I), panel inferior).

Del análisis por inmunotransferencia en condiciones no reductoras (Figura 3(II), panel superior) se desprende que las distintas isoformas conservan un patrón de proteína inmunoreactiva a LH similar al USDA-bLH-B5, siendo la proteína de $36.5 \mathrm{kDa}$ una de las bandas de proteína importantes, que en condiciones reductoras prácticamente desaparece y se incrementan las proteínas de menor peso molecular (23.4 y $20.8 \mathrm{kDa})$.

Las curvas de desplazamiento que se obtuvieron con el radioinmunoensayo para las diferentes isoformas de la LH y la fracción CM-3ab en comparación con el estándar de referencia se presentan en la Figura 4. La actividad inmunológica referida como el parámetro IC50 mostró un valor similar entre el USDA-bLH-B5 y la fracción CM-3ab (Figura 4(II)). En contraste, el valor de IC50 del estándar fue significativamente menor al de las isoformas, que indica que el estándar es inmunológicamente más activo ante el anticuerpo utilizado. Las pendientes de las curvas dosis-respuesta del estándar y las de las isoformas no fueron estadísticamente diferentes, lo que denota la identidad de las proteínas (Figura 4(III)).

La cantidad de AMPc producido por las células HEK-293 después de $24 \mathrm{~h}$ de tratamiento con las diferentes dosis de LH inmunoreactiva del estándar o con cada isoforma de LH se ejemplifica en la Figura 5(I). La producción de AMPc fue dependiente de la dosis y el cálculo del parámetro EC50 como indicativo de actividad
Under the studied bioassay conditions, the response patterns for the different bovine $\mathrm{LH}$ isolates were dose-dependent between 6.5 and $100 \mathrm{ng}$ immunoreactive LH. Production of cAMP was unaltered at higher doses and even exhibited a decline. This response pattern could indicate desensitizing of the limited number of receptors in the HEK-293 cells through a relatively slow down-regulation process of the

Figura 5. Producción de AMPc por las células HEK-293 con el estímulo de bLH y sus isoformas. I) Dosis-respuesta para la isoforma básica $(B)$, neutra $(C)$ y ácida $(E)$. II) Respuesta normalizada en la producción de AMPc por dosis de LH inmunoreactiva. III) Análisis de las curvas dosis-respuesta. Los resultados presentan el promedio de tres ensayos independientes por isoforma.

Figure 5. AMPc production in HEK-293 cells after stimulation with different isoforms of LH. I) Dose-response pattern isoforms to basic $(B)$, neutral $(C)$ and acidic $(E)$. II) Normalized response pattern in CAMP production by LH immunoreactive dose. III) Analysis parameters of the dose-response curve. Each point represents the mean of three independent assays for each isoform
I

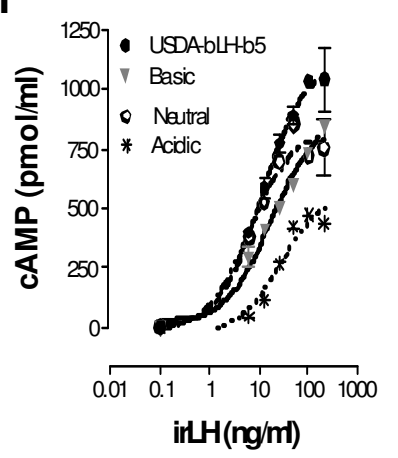

\|

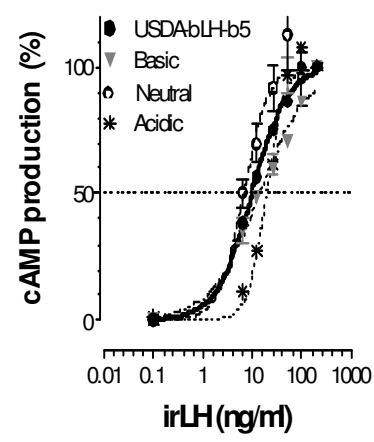

III Surmary of the LHdosedependent effect oncAMPproduction by HEK-293œlls

\begin{tabular}{|c|c|c|c|}
\hline Homme & $\mathrm{EC}_{50}$ & $\mathrm{~h}$ & $\mathrm{R}^{2}$ \\
\hline USDA-bLH-b5 & 967 & 124 & 0.964 \\
\hline Basic & $14.01^{\star a}$ & $0.90^{* a}$ & 0.980 \\
\hline Neural & $63^{\star b}$ & 1.81 & 0.931 \\
\hline Acidic & $18.96^{\star c}$ & $2.46^{\star b}$ & 0.982 \\
\hline
\end{tabular}


biológica sobre la curva dosis-respuesta normalizada (Figura 5(II)) resultó diferente entre las isoformas y el estándar, con la isoforma neutra más activa biológicamente con un EC50 menor; en contraste, la isoforma ácida mostró la menor actividad biológica con un EC50 mayor (Figura 5(III)). El valor de la pendiente (h) del estándar con respecto a la isoforma básica y la ácida denotó diferencias significativas, en tanto que al comparar la pendiente del estándar con la isoforma neutra no se observó diferencia (Figura 5(III)).

\section{DISCUSIÓN}

El polimorfismo de la LH de mamíferos se refleja en sus propiedades fisicoquímicas, inmunológicas y biológicas. La actividad biológica de distintos aislados de la LH hipofisaria de rumiantes se ha determinado con bioensayos in vivo $(13,14,15)$ e in vitro $(16,17)$ con resultados que indican que las isoformas básicas son las proteínas más bioactivas in vitro, en tanto que la mayor respuesta in vivo lo generan las isoformas ácidas. En años recientes el desarrollo de bioensayos usando líneas celulares que expresan receptores para gonadotropinas ha permitido evaluar proteínas biológicamente funcionales $(20,30)$.

El presente estudio evaluó la actividad biológica de distintas isoformas de carga de $\mathrm{LH}$ de la hipófisis bovina utilizando por primera vez el bioensayo in vitro de las células HEK-293 transfectadas con el cDNA para el receptor de la $\mathrm{LH}$ de rata(20) con resultados que mostraron diferencias significativas en la producción cuantitativa de AMPc por unidad de LH inmunoreactiva, siendo la isoforma de tipo neutro la que resultó la más activa al comparar su efecto con su análoga básica y ácida.

En este estudio, y bajo las condiciones del bioensayo, el patrón de respuesta con los diferentes aislados de LH bovina fue dependiente de la dosis en el rango de 6.5 a $100 \mathrm{ng}$ de LH inmunoreactiva, mientras que la producción de AMPc a dosis mayores no se modificó, más aún se presentó una caída en la producción. Este number of receptors in each cell(22). However, it could also be a product of the relatively rapid process of a decrease in the $\mathrm{LH}$ receptor's capacity to interact with and activate its related $\mathrm{G}$ proteins $(31)$. Time-dependent cAMP production was not analyzed in the present study, but $24 \mathrm{~h}$ of stimulus allowed an evaluation of differential changes in cAMP production between isoforms.

The greater response of the basic isoform compared to that of the acidic isoform coincided with the biological effect reported after placing different doses of diabetic and obese rat hypophysis eluted at basic and acidic pHs in HEK-293 cells $(20,21)$. It is a response pattern also seen in vitro in primary Leydig cell cultures after stimulus with human(32), rat(33) and ovine(17) LH hypophysis isoforms, as well as with basic isoforms present in circulation(16).

Why biological activity differed between the tested isoforms is not completely clear. Partial or total removal of some isoform oligosaccharide components by chemical or enzymatic means modifies their activity $(34,35)$, suggesting that one explanation may be the type of oligosaccharides in each isoform(4). For example, removal of the sulphate group in bovine LH containing only oligosaccharides with sulphated $\mathrm{N}$-acetylgalactosamine terminals (thus exposing the $\mathrm{N}$-acetylgalactosamine) produces greater $\mathrm{LH}$ depuration from the blood(36). This occurs due to easy recognition of the desulphated $\mathrm{LH}$ by the specific receptor in the liver (Gal/GalNAcspecific receptor), which proportionally reduces this protein's in vivo biological activity $(36,37)$.

Total removal of the oligosaccharide from $\mathrm{LH}$ has shown that deglycosilated hormones can no longer stimulate adenylate cyclase activity, although no apparent change occurs in receptor affinity(38). Deglycosilated hormones exhibit antagonistic functions in second messenger formation and production(39), and therefore on production of steroidal hormones(40). Variation in receptor affinity for each isoform may also have had an effect. Studies of bonding in HEK239 cells transfected with rat LH receptor cDNA have shown that there is a constant association 
patrón de respuesta en el bioensayo podría ser un indicativo de la desensibilización del número limitado de receptores presentes en las células HEK-293(22) a través de un proceso relativamente lento de regulación a la baja del número de receptores presentes en cada célula, o bien mediante el proceso relativamente rápido de la disminución en la capacidad del receptor de la LH de interactuar y activar a sus proteínas $G$ afines(31). Aunque en este estudio no se analizó la producción de AMPc dependiente del tiempo, $24 \mathrm{~h}$ de estímulo permitió evaluar el cambio diferencial en la producción de AMPc entre isoformas.

El patrón de respuesta mayor entre la isoforma básica con respecto a su análoga ácida de la LH bovina coincidió con el efecto biológico que se generó después de colocar diferentes dosis de extractos de hipófisis de rata diabética y obesa eluídos a pH básico o ácidos en las células HEK-293(20,21). Estos resultados también coincidieron con el patrón de respuesta generado in vitro en cultivos primarios de células de Leydig después del estímulo con isoformas hipofisarias de la LH humana(32); de rata(33); ovina(17), así como con las isoformas básicas presentes en la circulación(16).

La causa de la discrepancia en la actividad biológica entre las isoformas ensayadas no es del todo conocida, sin embargo, el o los mecanismos de esta diferencia biológica, se atribuye en parte al tipo de oligosacáridos que integran a cada isoforma(4), dado que la remoción total o parcial de algunos de los componentes de los oligosacáridos por medios químicos o enzimáticos modifican su actividad biológica(34,35). La LH bovina que contiene únicamente oligosacáridos con terminaciones de $\mathrm{N}$-acetilgalactosamina sulfatada(36), y la remoción del grupo sulfato que expone a la $\mathrm{N}$-acetilgalactosamina resulta en una mayor depuración de la hormona de la sangre, debido a su alto reconocimiento de la $\mathrm{LH}$ desulfatada por el receptor específico presente en el hígado (Gal/GalNAc-receptor específico), reduciendo proporcionalmente la actividad biológica in vivo de la proteína(36,37). at different orders of magnitude between different mammal LHs(22). Bovine LH exhibits the lowest affinity for the $\mathrm{LH}$ receptor, even though it has repeated leucine-rich regions (LRR; specifically leucine $3,7,8$ and 9) in the receptor's extracellular domain that are specifically for recognizing this hormone(22).

It can therefore be inferred that CAMP production after treatment with the different isoforms could also depend on differentiated affinity in the receptor. This makes it highly probable that the LH's glycosylation pattern is what regulates the differential pattern in biological response measured as CAMP production by HEK-239 cells after stimulation with different $\mathrm{LH}$ isoforms. Proteins with distinct receptor affinities can be produced as a result, the interaction of which can be reflected in changes in biological response quantified as cAMP production by cells.

The present data on isoform biological activity will complement the limited data currently available. To date, the neutral isoform in $\mathrm{LH}$ from ruminants and other species has not been immunologically or biologically characterized, possibly because it is difficult to purify and characterize due to its low content in the adenohypophysis $(13,40,41)$ and the blood(6). The bioactivity recorded in the neutral isoform in the present study is a valuable addition to biological evaluation of the bovine LH isoform spectrum. For the basic isoform, the observed biological activity complements previous reports on ovine(17), bovine(13) and rat $\mathrm{LH}^{(33)}$ in which the basic isoform exhibits greater in vitro bioactivity than the acidic isoform. Under the in vitro bioassay conditions used here, the isoforms exhibited differential bioactivity, but use of a homologous bioassay is desirable because it would provide superior analysis of LH isoforms in ruminants.

Quantitative immunoreactive $\mathrm{LH}$ concentration in the $\mathrm{LH}$ isoforms isolated from the bovine adenohypophysis was measured using USDAbLH-B5 as a reference. The RIA response 
Por otro lado, la remoción total del oligosacárido de la LH, ha confirmado que las hormonas deglicosiladas pierden su acción estimuladora sobre la actividad de la adenilato ciclasa, sin que se aprecie un cambio en su afinidad por el receptor(38). Con ello, se ha observado que las hormonas deglicosiladas presentan funciones antagónicas en la inducción de la formación y producción de segundos mensajeros(39) y por ende sobre la producción de hormonas esteroides(40). Finalmente, no se puede descartar la posible participación del receptor por diferencias en la afinidad por cada isoforma. Estudios de unión en células HEK-293 transfectadas con el cDNA para el receptor de la LH de rata(22), demostraron que existe una constante de asociación con diferente orden de magnitud entre distintas LH de mamíferos, siendo la LH bovina la que presentó la menor afinidad por el receptor de $\mathrm{LH}$, a pesar de contar con las regiones repetidas ricas en leucina (LRR) 3, 7, 8 y 9 en el dominio extracelular del receptor, específicas para el reconocimiento de esta hormona(22).

Con base en este estudio se puede inferir que la producción de AMPc después del tratamiento con los diferentes tipos de isoformas depende también de la afinidad diferenciada del receptor. Por lo tanto, basados en esta serie de resultados se puede establecer que el patrón diferencial en la respuesta biológica sobre la producción de AMPc por las células HEK-293 a través del estímulo con las distintas isoformas de la $\mathrm{LH}$ está regulado por el patrón de glicosilación de la $\mathrm{LH}$, que puede dar origen a proteínas con distinta afinidad por su receptor, y cuya interacción se refleje en un cambio en la respuesta biológica medida como la producción de AMPc por las células.

Adicionalmente, hasta donde se sabe, la caracterización inmunológica y biológica para la isoforma de tipo neutro en rumiantes y otras especies no se ha reportado, debido posiblemente a su bajo contenido en la adenohipófisis $(13,40,41)$ y en el suero(6), lo que genera dificultad para su caracterización y purificación. Con el resultado pattern depended in the amount of assayed protein, exhibiting similar values between the slopes, indicating the proteins are analogous. Values for IC50 were also similar among elution proteins in the same basic $\mathrm{pH}$ range (USDAbLH-B5; CM-3ab; and basic isoform $\mathrm{B}, \mathrm{pH}$ 9.58$8.41)$. However, they increased significantly in the neutral and acidic isoforms, suggesting a progressive decrease in LH immunological activity.

Distinct immunological activity between isoforms can be attributed to use of a polyclonal antibody in the RIA which is specifically focused against native oLH (NIDDK-oLH-26), a protein isolated using a procedure similar to that described here. A number of studies have shown that pure forms of LH contain different components. In a study using Nal125-labelled USDA-bLH-B5 analyzed using chromatofocusing( $(9)$, this reference $\mathrm{LH}$ exhibited a basic type distribution pattern in which $80 \%$ of the LH eluted in a basic $\mathrm{pH}$ range, while the rest of the labelled protein eluted in neutral and acidic $\mathrm{pH}$ gradients. This may indicate that the antibody generated for oLH, used in the immunodiagnostic, is mostly focused on basic isoforms with little emphasis on neutral and acidic proteins in LH. A clear advantage therefore exists for isoforms recovered at extremely basic $\mathrm{pH}$ (e.g. isoform A). Neutral and acid isoforms require more protein for this antibody to identify them.

The increasing amount of protein in each isoform could interfere in their biological response due to possible contamination from proteins structurally related to $\mathrm{LH}$ which remain present throughout purification and in the final products. However, this is unlikely since the anti-oLH antibody had been shown to be highly specific in quantifying $\mathrm{LH}$ in serum and ruminant hypophysis extracts without generating cross reactions with structurally related proteins such as $\mathrm{FSH}$ and $\mathrm{TSH}(9,11)$.

All the isoforms were recognized by the same antibody, although specificity was greatest in the basic isoform group. This was reflected in 
de la bioactividad de la isoforma neutra se complementa la valoración biológica del espectro de isoformas de LH bovina. Por otra parte, el resultado de la actividad biológica reportado en este estudio para la isoforma básica complementa a lo reportado en la LH ovina(17), bovina(13) y de rata(33) en donde la isoforma básica muestra una mayor actividad biológica in vitro con relación a la isoforma ácida. A pesar de que bajo las condiciones de desarrollo del bioensayo in vitro se observó un efecto diferencial en la actividad biológica entre isoformas, es deseable contar con un bioensayo homólogo de este tipo, que permita un mejor análisis para las isoformas de la LH de rumiantes.

La concentración cuantitativa de $\mathrm{LH}$ inmunoreactiva se determinó en las distintas isoformas de LH aisladas de la adenohipófisis bovina, tomando como referencia al USDA-bLHB5; el patrón de respuesta en el RIA fue dependiente de la cantidad de proteína ensayada. El valor entre pendientes fue similar, lo que denotó identidad entre proteínas. De forma interesante, el cálculo de la dosis al $50 \%$ de inhibición (IC50) como un referente de la actividad inmunológica fue similar entre proteínas de elución en el rango básico (USDAbLH-B5, fracción CM-3ab y la isoforma básica $\mathrm{B}, \mathrm{pH}$ 9.58-8.41), en tanto que en la isoforma neutra y las isoformas ácidas, el valor de IC50 se incrementó significativamente, lo que se interpretó como proteínas con menor actividad inmunológica de LH.

Esta discrepancia en la actividad inmunológica entre isoformas se puede atribuir a que para el desarrollo del RIA se utilizó un anticuerpo policlonal dirigido específicamente contra la oLH nativa (NIDDK-oLH-26), proteína que se obtuvo con un procedimiento similar al descrito en este estudio. Diversos estudios han demostrado que formas puras de la $\mathrm{LH}$ contienen diferentes componentes. El patrón de referencia USDAbLH-B5 radiomarcado con Na125I y analizado en el cromatoenfoque mostró un patrón de distribución de tipo básico, en donde el $80 \%$ the amount of protein required to attain the IC50 dose in the system, which was significantly lower in the other analyzed isoforms. Calculation of each isoform's immunological activity using the LH-specific heterologous assay may be adequate, but more accurate immunological evaluation will require developing a specific homologue system for each isoform.

Glycoprotein extract (GPE) was generated in the extraction process with the hypophysis anterior lobes. Purification of the GPE in the CM-Sepharose exchanger produced CM-3ab, a protein fraction containing the greatest amount of immunoreactive LH. Its physicochemical, immunological and biological characteristics were similar to those of the reference, and its chromatofocusing distribution pattern was similar to that of adenohypophysis tissue in bovines $(42,43,44)$, caprines $(14)$ and humans $(45)$. Use of the chromatofocusing technique resulted in higher LH yield ( $\mu \mathrm{g} \mathrm{LH} / \mathrm{mg}$ protein) than reported in other species and using other techniques $(15,17,44)$.

Of the isoforms isolated from CM-3ab using chromatofocusing, LH immunoreactive proteins in the basic $\mathrm{pH}$ range dominated. Similar distribution patterns have been reported in ovine species(42), and in the elution patterns of ovine $(46)$ and bovine hypophysis extracts $(11,47)$. It can therefore be assumed that the procedure developed here to isolate isoform groups from bovine $\mathrm{LH}$ does not interfere in the isoform distribution patterns of bovine $\mathrm{LH}$.

In NR conditions, the isoform group isolated from the hypophysis anterior lobe had the same molecular weight as the reference standard, which corresponds to the $36.5 \mathrm{kDa}$ heterodimer. Under R conditions, the dominant presence of proteins with 20.8 and $23.0 \mathrm{kDa}$ molecular weights corresponds to alpha- and beta- $\mathrm{LH}$, respectively, and with values reported for native LH and its subunits $(13,14,15)$. Pattern analysis of the acidic isoform under NR conditions showed a series of high molecular weight proteins that disappeared after treatment with the reducing 
de la LH eluyó en este rango de pH, y el resto de la proteína radiomarcada eluyó en el rango de $\mathrm{pH}$ neutro y ácido del gradiente(9), resultado que puede ser un indicativo que el anticuerpo generado para oLH y que se utilizó para el inmunodiagnóstico está dirigido en su mayoría para isoformas básicas, y escasamente para proteínas neutras y ácidas de la $\mathrm{LH}$, lo que le genera una ventaja de inmunodetección sobre aquellas isoformas recuperadas a $\mathrm{pH}$ extremadamente básico, como resulta con la isoforma $A$, por lo que neutras y ácidas requirieron mayor cantidad de proteína requerida para ser identificadas por el anticuerpo.

El incremento en la cantidad de proteína para cada isoforma podría interferir en la respuesta biológica debido a la presencia de posibles contaminantes de proteínas estructuralmente relacionadas con la $\mathrm{LH}$, y que como se sabe durante la purificación, están presentes hasta los productos finales; sin embargo, esta posibilidad se puede descartar dado que se demostró previamente la alta especificidad del anticuerpo anti-oLH para cuantificar LH del suero y de extractos de hipófisis de rumiantes sin generar ninguna reacción cruzada con proteínas como la FSH y TSH estructuralmente emparentadas $(9,11)$.

Todas las isoformas se reconocieron por el mismo anticuerpo, sin embargo, la mayor especificidad se presentó con el grupo de isoformas básicas que se reflejó en la cantidad de proteína requerida para alcanzar la dosis IC50 en el sistema, y que fue significativamente inferior con el resto de las isoformas analizadas. Aunque podemos inferir que el cálculo de la actividad inmunológica para cada isoforma con el ensayo heterólogo específico para $\mathrm{LH}$ es adecuado, se debe considerar que para una mejor valoración inmunológica se requiere del desarrollo de un sistema homólogo y específico para cada isoforma.

Durante el proceso de extracción de los lóbulos anteriores de la hipófisis se generó el extracto glicoprotéico, a partir del cual y después de su agent $\beta$-mercaptoethanol. This suggests the presence of molecular aggregates of LH.

Electrophoretic analysis under $\mathrm{R}$ conditions of $\mathrm{CM}-3 \mathrm{ab}$, and the $\mathrm{C}$ and $\mathrm{D}$ isoforms showed them all to be characterized by the presence of a $17 \mathrm{kDa}$ protein, which was absent in isoform $A$ and barely present in isoform $B$. Because this protein was not identified in the immunotransference analysis, it is probably a contaminating protein concentrated between $\mathrm{pH} 7.98$ and 5.41. It may correspond to one of the isoforms of bovine $\mathrm{FSH}(11)$, which elute in this $\mathrm{pH}$ range. Another possibility is that it is an immature form of one of the subunits. A protein with a molecular weight similar to that described here was identified in electrophoretic analysis under $\mathrm{R}$ conditions of deglycosilated ovine $\mathrm{LH}(48)$. Some of the subunits may also have experienced proteolytic breakage, as described for fractionated proteins of human $\mathrm{LH}$ with a similar molecular weight(49). Presence of this protein type in some isoform isolates does not correspond to $\mathrm{LH}$, although it could interfere in the interaction between $\mathrm{LH}$ and it receptor, thus modifying the strength of its biological activity.

\section{CONCLUSIONS AND IMPLICATIONS}

Isoforms of bovine luteinizing hormone have differing biological activities. Differences in the strength of in vitro biological activity between LH isoforms suggest that some may experience changes during the isoform synthesis process. This may represent a fine-tuned regulation mechanism of gonadal function in the adenohypophysis. Isoform biological activity was quantified using an in vitro heterologous bioassay, which does not truly reflect each isoform's physiological response in the organism as a whole. However, this technique did prove the presence of differential biological response among the tested isoforms. Confirming each isoform's affinity and selective specificity will require use of HEK-239 cells transfected with bovine LH (homologue) receptor cDNA.

End of english version 
purificación en el intercambiador CM-sepharosa dio origen a la fracción $\mathrm{CM}$-3ab, fracción de proteína que agrupó a la mayor cantidad de $\mathrm{LH}$ inmunoreactiva. Esta fracción de proteína mostró características fisicoquímicas, inmunológicas y biológicas similares al patrón de referencia, además su patrón de distribución en el cromatoenfoque se asemejó al patrón observado del tejido adenohipofisario de esta especie $(42,43,44)$, la especie caprina(14) y humana(45). Adicionalmente, con el empleo del cromatoenfoque, el rendimiento de LH ( $\mu \mathrm{g}$ de LH/mg de proteína) resultó superior a lo reportado en otras especies que aislaron a esta proteína con diferentes procedimientos $(15,17,44)$.

Las isoformas aisladas a partir de la fracción CM-3ab mediante el cromatoenfoque representaron diferentes proporciones, donde predominaron las proteínas inmunoreactivas a LH que eluyeron en el rango de pH básico. Este patrón de distribución resultó similar aunque no idéntico al observado en la especie ovina(42), así como al patrón de elución que se observó durante el análisis de extractos hipofisarios ovinos(46) y bovinos(11,47), en donde las isoformas aisladas de tipo básico predominaron. Por lo tanto, se puede asumir que el procedimiento desarrollado para la obtención del grupo de isoformas de la $\mathrm{LH}$ bovina no interfiere en el patrón particular de distribución de isoformas que muestra la LH en esta especie.

El grupo de isoformas aisladas del lóbulo anterior de la hipófisis tuvo el mismo peso molecular que el estándar de referencia en condiciones no reductoras, correspondiente al heterodímero de $36.5 \mathrm{kDa}$. La presencia de proteínas predominantes con peso molecular de $20.8 \mathrm{kDa}$ y $23.0 \mathrm{kDa}$ en el gel electroforético en condiciones reductoras, corresponde a las subunidades alfa y beta de la $\mathrm{LH}$, respectivamente, lo que coincide con los valores reportados para la forma nativa de esta hormona y sus subunidades $(13,14,15)$. El análisis del patrón electroforético en condiciones no reductoras de la isoforma ácida, presentó una serie de proteínas con alto peso molecular, que después del tratamiento con el agente reductor, $\beta$-mercaptoetanol, desaparecieron, lo que hace pensar en agregados moleculares de la LH.

El análisis electroforético en condiciones reductoras de la fracción $\mathrm{CM}$-3ab, isoforma $\mathrm{C}$ e isoforma $\mathrm{D}$ se caracterizó por la presencia de una proteína de $17 \mathrm{kDa}$, ausente en la isoforma A y ligeramente presente en la isoforma $B$. Esta proteína durante el análisis por inmunotransferencia no se identificó, lo que sugiere que se trata de una proteína contaminante que se concentró entre el pH 7.98 a 5.41 y que puede corresponder a alguna de las isoformas de la FSH bovina(11), que eluyen en este rango de $\mathrm{pH}$. La otra posibilidad es que se trate de una forma inmadura de alguna de la subunidades. Estudios electroforéticos en condiciones reductoras con LH ovina deglicosilada(48) han identificado una proteína con un peso molecular similar al descrito en este estudio. No se descarta la posibilidad de un rompimiento proteolítico de alguna de las subunidades, como se ha descrito para proteínas fraccionadas de LH humana que presentan un peso molecular similar(49). Por lo tanto, aunque existe la presencia de este tipo de proteína en aislados de determinadas isoformas, su presencia no corresponde a $\mathrm{LH}$, aunque probablemente pueda interferir en la interacción de la hormona con su receptor, modificando la estimación de su potencia biológica.

\section{CONCLUSIONES E IMPLICACIONES}

Los resultados de este estudio indican que las isoformas de la hormona luteinizante bovina tienen diferente potencia biológica. El hallazgo de un cambio en la potencia biológica in vitro entre isoformas de la LH sugiere la posibilidad que durante el proceso de síntesis de las isoformas en la especie bovina, ocurran cambios para una mayor o menor proporción de algunas de ellas, y que éste pueda representar un mecanismo fino de regulación a nivel de la adenohipófisis sobre la función gonadal. Aunque en este estudio la actividad biológica de las isoformas de la LH bovina se determinó con un 
bioensayo heterólogo in vitro, que no es el verdadero reflejo de la respuesta fisiológica de cada isoforma en un organismo entero, se pudo constatar que la respuesta biológica a las distintas isoformas es diferencial; sin embargo, es necesario contar con células HEK-293 transfectadas con el cDNA para el receptor de la LH bovina (homólogo) y confirmar la afinidad y especificidad selectiva de cada isoforma.

\section{LITERATURA CITADA}

1. Zeleznik AJ. The physiology of follicle selection. Reprod Biol Endocrinol 2004;16(2):31-37.

2. Bao B, Garverick HA. Expression of steroidogenic enzyme and gonadotropin receptor genes in bovine follicles during ovarian follicular waves: a review. J Anim Sci 1998;76(7):1903-1921.

3. Niswender GD, Juengel JL, Silva PJ, Rollyson MK, McIntush EW. Mechanisms controlling the function and life span of the corpus luteum. Physiol Rev 2000;80(1):1-29.

4. Baenziger JU, Green ED. Pituitary glycoprotein hormone oligosaccharides: structure, synthesis and function of the asparagine-linked oligosaccharides on lutropin, follitropin and thyrotropin. Biochim Biophys Acta 1988;947(2):287-306.

5. Baenziger JU, Kumar S, Brodbeck RM, Smith PL, Beranek MC. Circulatory half-life but not interaction with the lutropin/ chorionic gonadotropin receptor is modulated by sulfation of bovine lutropin oligosaccharides. Proc Natl Acad Sci USA 1992;89(1):334-338.

6. Arrieta E, Porras A, González-Padilla E, Murcia C, Rojas S, Perera-Marín G. Ovine serum and pituitary isoforms of luteinising hormone during the luteal phase. Reprod Fertil Dev 2006;18(4):485-495.

7. Cooke DJ, Crowe MA, Roche JF. Circulating FSH isoform patterns during recurrent increases in FSH throughout the oestrous cycle of heifers. J Reprod Fertil 1997;110(2):339345.

8. Keel BA, Grotjan HE, Jr. Characterization of rat lutropin charge microheterogeneity using chromatofocusing. Anal Biochem 1984;142(2):267-270.

9. Perera-Marín G, Murcia C, Rojas S, Hernández-Cerón J, González-Padilla E. Pattern of circulating luteinizing hormone isoforms during the estrous and luteal phases in Holstein heifers. Anim Reprod Sci 2005;86(1-2):53-69.

10. Rojas-Maya S, González-Padilla E, Murcia-Mejía C, OlivaresSegura A, Hernández-Cerón J, Perera-Marín G. Caprine luteinizing hormone isoforms during the follicular phase and anestrus. Anim Reprod Sci 2007;100(3-4):280-290.

11. Perera-Marín G, Gutiérrez CG, Murcia C, León H, GonzálezPadilla E. Progesterone and the distribution of pituitary gonadotropin isoforms in cattle. Anim Reprod Sci 2008;104(2-4):164-176.

12. Sairam MR, Zaky AA, Hassan AA. Isolation and characterization of distinct bioactive forms of $\mathrm{LH}$ from male buffalo pituitaries: differences localized to their alpha subunits. J Endocrinol 1994;143(2):313-323.

13. Perera MG, Falcón AA, Murcia MC, Hernández CJ, González PE. Purificación de cinco isoformas de la hormona luteinizante bovina (bLH). Caracterización fisicoquímica, biológica e inmunológica. Vet Mex 2004;35(2):129-145.

14. Perera MG, Ortiz RF, Gamboa VJJ, Reynoso MW, Falcón AA, Salas VA. Obtención, purificación y caracterización de dos formas de hormona luteinizante de la adenohipófisis caprina (gLH). Vet Mex 1996;1(27):1-10.

15. Chaudhary R, Muralidhar K. Caprine (Capra hircus) luteinizing hormone: purification and chromatographic investigation of its different isoforms. Prep Biochem Biotechnol 2007;37(3):277-300.

16. Hejl KM, Wolfe MW, Kinder JE, Grotjan HE. Bioactive and immunoreactive concentrations of circulating luteinizing hormone during sexual maturation in the bovine. Biol Reprod 1992;46(6):1205-1210.

17. Nakamura $Y$, Nomura $K$, Watanabe $M$, Ujihara $M$, Demura $\mathrm{H}$. Comparison of biological aspects among ovine luteinizing hormone isoforms with charge heterogeneity. Endocr J 1993;40(1):73-81.

18. McFarland KC, Sprengel R, Phillips HS, Köhler M, Rosemblit $\mathrm{N}$, Nikolics $\mathrm{K}$, et al. Lutropin-choriogonadotropin receptor: an unusual member of the $\mathrm{G}$ protein-coupled receptor family. Science 1989;4;245(4917): 494-499.

19. Loosfelt H1, Misrahi M, Atger M, Salesse R, Vu Hai-Luu Thi MT, Jolivet A, et al. Cloning and sequencing of porcine LHhCG receptor CDNA: variants lacking transmembrane domain. Science 1989;4;245(4917):525-528.

20. Olivares A, Mendez JP, Cardenas M, Oviedo N, Palomino MA, Santos I, et al. Pituitary-testicular axis function, biological to immunological ratio and charge isoform distribution of pituitary LH in male rats with experimental diabetes. Gen Comp Endocrinol 2009;161(3):304-312.

21. Olivares A, Mendez JP, Zambrano E, Cardenas M, Tovar A, Perera-Marín G, et al. Reproductive axis function and gonadotropin microheterogeneity in a male rat model of diet-induced obesity. Gen Comp Endocrinol 2010;166(2):356364.

22. Galet $\mathrm{C}$, Ascoli M. The differential binding affinities of the luteinizing hormone (LH)/choriogonadotropin receptor for $\mathrm{LH}$ and choriogonadotropin are dictated by different extracellular domain residues. Mol Endocrinol 2005;19(5):1263-1276.

23. Laemmli UK. Cleavage of structural proteins during the assembly of the head of bacteriophage T4. Nature 1970;227(5259):680-685.

24. Bollag DM, Edelstein SJ. Protein Methods. 1st ed. New York, USA: Wiley-Liss Inc.; 1991.

25. Towbin H, Staehelin T, Gordon J. Electrophoretic transfer of proteins from polyacrylamide gels to nitrocellulose sheets: procedure and some applications. Proc Natl Acad Sci USA 1979;76(9):4350-4354.

26. Borromeo V, Amsterdam A, Berrini A, Gaggioli D, Dantes A, Secchi C. Characterization of biologically active bovine pituitary FSH purified by immunoaffinity chromatography using a monoclonal antibody. Gen Comp Endocrinol 2004;139(2):179-189.

27. DeLean A, Munson PJ, Rodbard D. Simultaneous analysis of families of sigmoidal curves: application to bioassay, 
radioligand assay, and physiological dose-response curves. Am J Physiol 1978;235(2):E97-E102.

28. Rosenfield RL, Helke J. Is an immunoassay available for the measurement of bioactive LH in serum? J Androl 1992;13(1):1-10.

29. Hunter WM, Greenwood FC. Preparation of iodine-131 labelled human growth hormone of high specific activity. Nature 1962;5(194):495-496.

30. Minegishi Y, Dirks RP, de Wijze DL, Brittijn SA, Burgerhout $\mathrm{E}$, Spaink HP, et al. Quantitative bioassays for measuring biologically functional gonadotropins based on eel gonadotropic receptors. Gen Comp Endocrinol 2012;178(1):145-152.

31. Galet C, Min L, Narayanan R, Kishi M, Weigel NL, Ascoli M. Identification of a transferable two-amino-acid motif (GT) present in the $\mathrm{C}$-terminal tail of the human lutropin receptor that redirects internalized $\mathrm{G}$ protein-coupled receptors from a degradation to a recycling pathway. Mol Endocrinol 2003;17(3):411-22.

32. Robertson DM, Diczfalusy E. Biological and immunological characterization of human luteinizing hormone: II. A comparison of the immunological and biological activities of pituitary extracts after electrofocusing using different standard preparations. Mol Cell Endocrinol 1977;9(1):5767.

33. Hattori M, Sakamoto K, Wakabayashi K. The presence of LH components having different ratios of bioactivity to immunoreactivity in the rat pituitary glands. Endocrinol Jpn 1983;30(3):289-296.

34. Hortin G, Natowicz M, Pierce J, Baenziger J, Parsons T, Boime I. Metabolic labeling of lutropin with [35S] sulfate. Proc Natl Acad Sci USA 1981;78:7468-7472.

35. Galway $A B$, Hsueh $A J$, Keene $J L$, Fauser BC, Boime I. In vitro and in vivo bioactivity of recombinant human folliclestimulating hormone and partially deglycosylated variants secreted by transfected eukaryotic cell lines. Endocrinology 1990;127:93-100.

36. Fiete DJ, Srivatava V, Hindsgaul O, Baenzinger JU. A hepatic reticuloendothelial cell receptor specific for SO4-4GalNAC beta $1,4 \mathrm{GlcNAc}$ beta $1,2 \mathrm{Man}$ alpha that mediates rapid clearance of lutropin. Cell 1991;67:1103-1110.

37. Fiete DJ, Beranek MC, Baenzinger JU. A cysteine-rich domain of the "mannose" receptor mediates GalNAc-4-SO4 binding. Proc Natl Acad Sci USA 1998;3:2089-2093.

38. Perlman $S$, van den Hazel $B$, Christiansen J, Gram-Nielsen $\mathrm{S}$, Jeppesen B, Andersen CKM et al. Glycosylation of an Nterminal extension prolongs the half-life and increases the in vivo activity of follicle stimulating hormone. J Clin Endocrinol Metab 2003;88,3227-3235.

39. Fares $\mathrm{F}$. The role of $\mathrm{O}$-linked and $\mathrm{N}$-linked oligosaccharides on the structure-function of glycoprotein hormones: development of agonists and antagonists. Biochim Biophys Acta 2006;1760 (4):560-567.

40. Ulloa-Aguirre A, Midgley AR, Jr., Beitins IZ, Padmanabhan V. Follicle-stimulating isohormones: characterization and physiological relevance. Endocr Rev 1995;16(6):765-787.

41. Kojima FN, Cupp AS, Stumpf TT, Zalesky DD, Roberson MS, Werth LA, et al. Effects of 17 beta-estradiol on distribution of pituitary isoforms of luteinizing hormone and folliclestimulating hormone during the follicular phase of the bovine estrous cycle. Biol Reprod 1995;52(2):297-304.

42. Zalesky DD, Grotjan HE. Comparison of intracellular and secreted isoforms of bovine and ovine luteinizing hormone. Biol Reprod 1991;44(6):1016-1024.

43. Stumpf TT, Wolfe MW, Roberson MS, Caddy G, Kittok RJ, Schanbacher BD, et al. Bovine luteinizing hormone (LH) isoforms and amounts of messenger ribonucleic acid for alpha- and LH beta-subunits in pituitaries of cows immunized against LH-releasing hormone. Biol Reprod 1992;47(5):776781.

44. Carranza SME, Amezcua MEV, Neri BR, Salas VA. Extracción y purificación de la hormona luteinizante bovina. Tec Pecu Mex 1994;32:5-17.

45. Stockell HA. Separation and partial purification of the protein hormones from human pituitary glands. J Biol Chem 1966;100:754-761.

46. Montero A, Olivares A, González-Padilla E, Murcia C, Diaz D, Gómez-Chavarín M, Perera-Marín G. Effect of ovine luteinizing hormone (oLH) charge isoforms on VEGF and cAMP production. [enviado a publicación].

47. Kojima FN, Cupp AS, Stumpf TT, Zalesky DD, Roberson MS, Werth LA, et al.Effects of 17 beta-estradiol on distribution of pituitary isoforms of luteinizing hormone and folliclestimulating hormone during the follicular phase of the bovine estrous cycle. Biol Reprod 1995;52:297-304.

48. Zalesky DD, Schanbacher BD, Grotjan HE. Effect of immunization against LHRH on isoforms of LH in the ovine pituitary. J Reprod Fertil 1993;99:231-235.

49. Manjunath $P$, Sairam MR, Schiller PW. Chemical deglycosylation of ovine pituitary lutropin. A study of the reaction conditions and effects on biochemical, biophysical and biological properties of the hormone. Biochem J 1982;1;207(1):11-19. 
